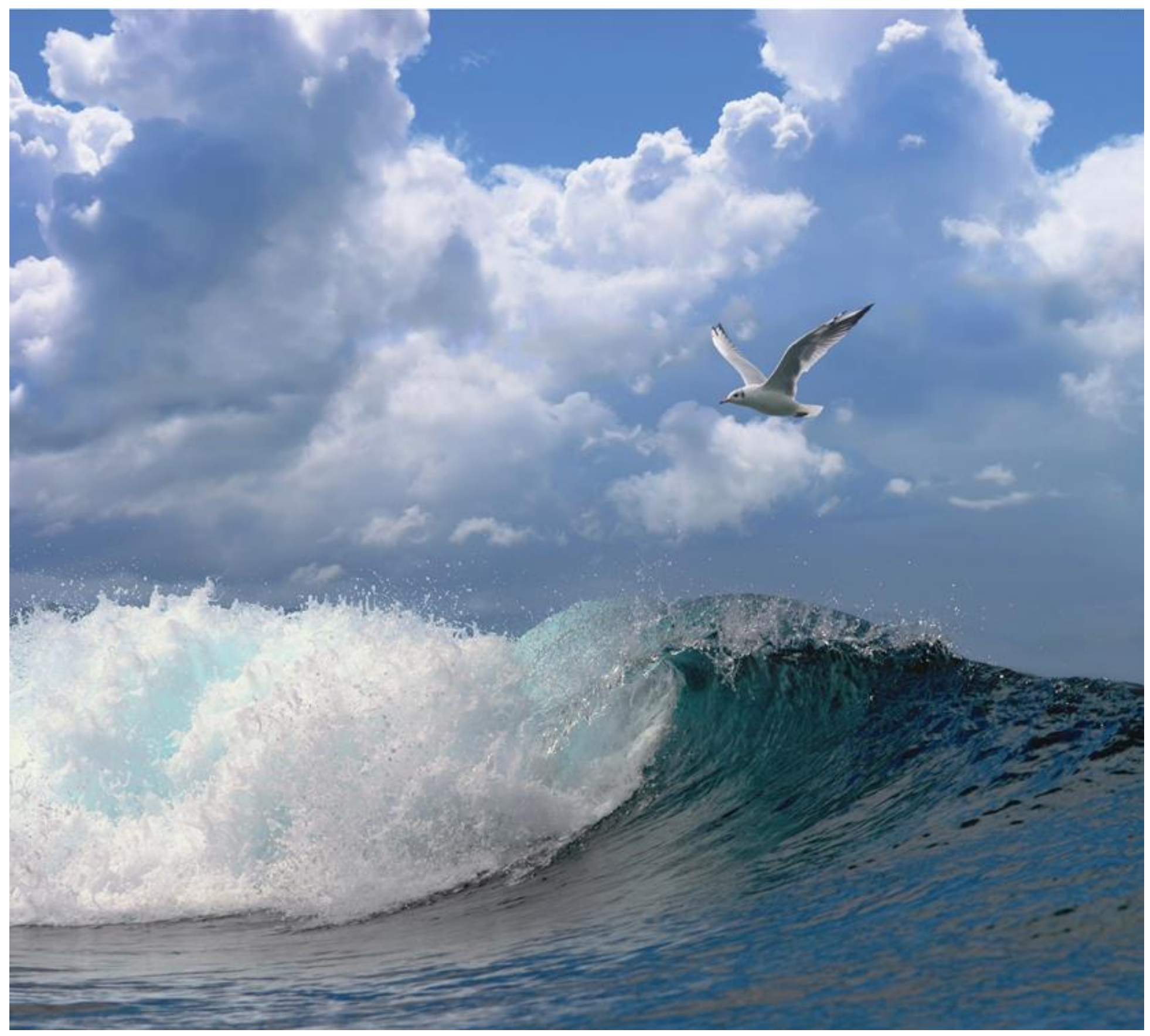

\title{
Effects of abiotic variables on the survival of discarded bycatches in North Sea pulse- trawl fisheries
}




\section{Effects of abiotic variables on the survival of discarded bycatches in North Sea pulse-trawl fisheries}

Author(s): $\quad$ Edward Schram ${ }^{1}$, Paul W. Goedhart ${ }^{2}$ and Pieke Molenaar ${ }^{1}$

1) Wageningen Marine Research, P.O. Box 68, 1970 AB, Ijmuiden.

2) Wageningen University and Research, Biometris, P.O. Box 16, 6700 AA Wageningen. 
Keywords: pulse trawling, discards survival probability, abiotic variables

Client: $\quad$ VisNed

Attn.: Wouter van Broekhoven

Postbus 59

8320 AB Urk

The Netherlands

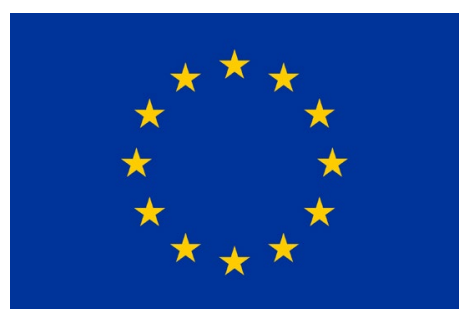

European Union, European Maritime and Fisheries Fund (EMFF)

This report can be downloaded for free from https://doi.org/10.18174/475614

Wageningen Marine Research provides no printed copies of reports

Wageningen Marine Research is ISO 9001:2015 certified.

\section{(C) Wageningen Marine Research}

Wageningen Marine Research, an institute Wageningen Marine Research accepts no liability for consequential damage, nor within the legal entity Stichting for damage resulting from applications of the results of work or other data Wageningen Research (a foundation under obtained from Wageningen Marine Research. Client indemnifies Wageningen Dutch private law) represented by Dr. Marine Research from claims of third parties in connection with this application. M.C.Th. Scholten, Managing Director All rights reserved. No part of this publication may be reproduced and / or

KvK nr. 09098104, published, photocopied or used in any other way without the written permission WMR BTW nr. NL 8113.83.696.B16.

Code BIC/SWIFT address: RABONL2U IBAN code: NL 73 RABO 0373599285 


\section{Contents}

Preface

Summary

$\begin{array}{ll}\text { Samenvatting } & 7\end{array}$

1 Introduction 9

2 Materials and Methods $\quad 10$

2.1 Data 10

2.1.1 Data collection - discards survival 10

$\begin{array}{ll}2.1 .2 & \text { Data collection - abiotic variables } \\ 2.1 .3 & 10\end{array}$

$\begin{array}{ll}2.1 .3 \text { Data selection } & 12\end{array}$

$\begin{array}{lll}2.2 & \text { Statistical procedures } & 12\end{array}$

$\begin{array}{lll}2.2 .1 & \text { Preliminary analyses } & 12\end{array}$

2.2.2 General procedure 12

$\begin{array}{ll}2.2 .3 \text { Stepwise model construction } & 13\end{array}$

$\begin{array}{llr}3 & \text { Results } & 14\end{array}$

$\begin{array}{lll}3.1 & \text { Correlations between abiotic variables } & 14\end{array}$

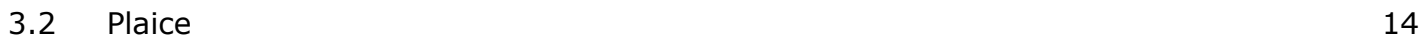

$\begin{array}{lll}3.2 .1 & \text { Effects of single abiotic variables } & 14\end{array}$

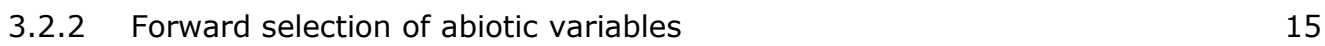

$\begin{array}{ll}3.2 .3 & \text { Interaction effects }\end{array}$

3.3 Sole $\quad 18$

3.3.1 Effects of single abiotic variables $\quad 18$

$\begin{array}{ll}\text { 3.3.2 Forward selection of abiotic variables } & 18\end{array}$

$\begin{array}{lll}3.4 & \text { Brill and thornback ray } & 20\end{array}$

$\begin{array}{lll}3.5 & \text { Turbot } & 20\end{array}$

$\begin{array}{lll}3.5 .1 & \text { Effect of single abiotic variables } & 20\end{array}$

$\begin{array}{lll}3.5 .2 & \text { Forward selection of abiotic variables } & 21\end{array}$

4 Discussion $\quad 23$

$\begin{array}{lll}4.1 & \text { Interaction between stressors and abiotic variables } & 23\end{array}$

$\begin{array}{ll}4.2 & \text { Plaice } \\ 4.3 & 25\end{array}$

$\begin{array}{lll}4.3 & \text { Sole } & 26\end{array}$

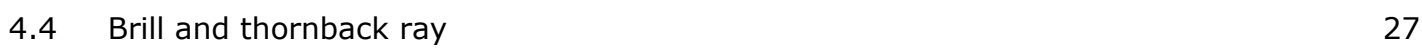

$\begin{array}{lll}4.5 & \text { Turbot } & 27\end{array}$

$\begin{array}{llr}4.6 & \text { Conclusions } & 28\end{array}$

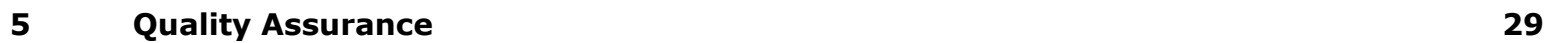

$\begin{array}{lr}\text { References } & 30\end{array}$

$\begin{array}{lr}\text { Justification } & 31\end{array}$ 


\section{Preface}

The project 'Survival of flatfish and ray discards' investigates four topics related to flatfish and ray discards survival in pulse-trawl fisheries with $12 \mathrm{~m}$ gears in the North Sea: 1 . Discards survival of undersized plaice, sole, turbot, brill, thornback ray and spotted ray in conventional pulse-trawl fisheries, 2. Measures to increase discards survival, 3. Abiotic variables affecting discards survival and 4. The use of vitality index scores as a proxy for discards survival.

Each topic will be reported separately and the current report is the third in the series of four reports delivered by the project. Utilization of methods and research data partly overlaps among the four topics. Each report can be read independently from the other reports in the series. Consequently the description of methods and reporting of data partly overlaps in the four reports.

The current report on the abiotic variables affecting discards survival not only uses data collected during the nine sea trips conducted during the current project 'Survival of flatfish and ray discards' but also data collected during the discards survival project conducted in 2015 (Van Marlen et al., 2016).

In a later stage, parts of the results presented in these four reports will be submitted for publication in peer-reviewed scientific journals. These four reports should be considered as pre-publications of final results.

The project was commissioned by VisNed and received financial support from the European Maritime and Fisheries Fund (EMFF) of the European Union.

March 2019 


\section{Summary}

The effects of conditions at sea during fishery activity on the survival probability of fish discarded by the $80 \mathrm{~mm}$ pulse trawl fisheries were assessed. The fish species included plaice, sole, turbot, brill and thornback ray. The conditions at sea were defined by the following nine abiotic variables: time in the catch sorting process, water depth, seafloor type, wave height, surface water temperature, air temperature, wind speed, total catch mass and haul duration. Data on discards survival probability and abiotic variables used in this study were previously collected in discards survival studies by Van Marlen et al. (2016), Schram and Molenaar (2018) and Molenaar and Schram (2018).

Included in the data were the treatments conventional pulse trawl fisheries (C) and water filled hopper (W) for plaice and sole sampled at the end of the sorting belt (s) and from the conveyor belt (c). This resulted in four treatments $\mathrm{Cs}, \mathrm{Cc}$, Ws and Wc for plaice and sole, while turbot, brill and thornback ray were only collected for conventional pulse trawl fisheries at the end of the sorting belt (Cs) and thus have no treatment levels. The total number of test-fish from all studies considered for which survival was observed 1694 for plaice, 751 for sole, 110 for turbot, 90 for brill and 94 for thornback ray. Since not all abiotic variables were recorded for each test-fish, the number of available observations depends on the abiotic variables used in an analysis.

Generalized linear mixed models were used to analyse the observed survival data. A fixed treatment effect was added to correct for differences in survival among treatments. A random sea trip effect was added to account for possible dependencies among hauls. First, the effect of single abiotic variables on survival probability was assessed, employing all the available data for that variable, to gain insights in the importance of individual abiotic variables. Second, a stepwise forward selection of the abiotic variables was performed to construct an explanatory model for survival probability. Finally interactions between treatment and abiotic variables were investigated. Based on this study we conclude the following:

- Survival probabilities of bycatches discarded in pulse trawl fisheries depend on the conditions at sea and operational characteristics of the fisheries. The abiotic variables that influence discards survival probability vary among species tested.

- Discards survival probability of plaice depends on the type of seafloor on which the trawling takes place in case a water filled hopper is used, with the highest survival for muddy seafloors and the lowest survival for stony seafloor. For example at a surface water temperature of $20^{\circ} \mathrm{C}$ the predicted discards survival probabilities were $42 \%$ (95\%CI $19-70 \%)$ on a muddy seafloor, $10 \%$ (95\%CI $5-18 \%)$ on a sandy seafloor and $1.7 \%$ (95\% CI $0.2-12 \%)$ for trawling on a stony seafloor. When using the conventional dry hopper, discards survival of plaice is not affected by the type of seafloor.

- The discards survival probability of plaice depends on the total catch mass in case a water filled hopper is used. When catches are small, survival is higher when a water filled hopper is used. For example the predicted survival probability when trawling on a sandy seafloor and a total catch mass of $500 \mathrm{~kg}$ is $18 \%$ (95\%CI $10-28 \%$ ) when a water filled hopper is used and $14 \%$ (95\%CI 9$22 \%$ ) when the conventional dry hopper is used. However, survival for the water filled hopper declines faster with increasing catch mass than is the case for the dry hopper, ultimately resulting in a lower survival for the water filled hopper. For a total catch mass of $1500 \mathrm{~kg}$ the predicted survival probability is $7 \%(95 \% \mathrm{CI} 2-19 \%)$ for the water filled hopper and $10 \%$ (95\%CI $4-25 \%)$ for the conventional dry hopper when trawling on a sandy seafloor.

- Discards survival probability of plaice also depends on the surface water temperature. Irrespective of hopper treatment, survival declines with increasing temperature. For example when trawling on a sandy seafloor, the predicted survival probability for the conventional dry hopper treatment 
ranged from $18 \%(95 \% \mathrm{CI} 11-28 \%)$ at $6^{\circ} \mathrm{C}$ to $7 \%(95 \% \mathrm{CI} 4-14 \%)$ at a surface water temperature of $20^{\circ} \mathrm{C}$.

- The discards survival probability of sole depends on total catch mass. Irrespective of the use of a dry or water filled hopper, survival declines with increasing catch mass. For example at a wave height of $1 \mathrm{~m}$ and when using the conventional dry hopper, the predicted survival probability is $22 \%(95 \%$ CI $14-32 \%)$ for a total catch mass of $500 \mathrm{~kg}$ and $11 \%$ (95\%CI $5-22 \%$ ) for a total catch mass of $1000 \mathrm{~kg}$.

- The discards survival probability of sole also depends on wave height. Irrespective of the use of a dry or water filled hopper, survival declines with increasing wave height. For example for a total catch mass of $1000 \mathrm{~kg}$ and when using the conventional dry hopper, the predicted survival probability is $15 \%(95 \% \mathrm{CI} 7-29 \%)$ at a wave height of $0.5 \mathrm{~m}$ and $6 \%(95 \% \mathrm{CI} 2-14 \%)$ at a wave height of $2 \mathrm{~m}$.

- For brill no effects of abiotic variables on discards survival probability could be detected, possibly because of a lack of observations. It is also possible that the species is very sensitive to fisheries related stressors and in many cases lethally affected by the capture, hauling and catch sorting process irrespective of the conditions at sea.

- For thornback ray some evidence was found for an effect of seafloor on discards survival probability similar to plaice.

- The discards survival probability of turbot depends on (air) temperature. Survival increases with increasing temperature.

- The discards survival probability of turbot also depends on wind speed (wave height) and total catch mass. Survival declines with increasing wind speed (wave height) and total catch mass.

- For turbot some evidence was found for an effect of time in the catch sorting process. Survival decreases with increasing time in the catch sorting process. 


\section{Samenvatting}

Wij onderzochten de effecten van de omstandigheden op zee op de overlevingskansen van vissen die door pulsvissers terug worden gezet in zee (discards). De onderzochte vissoorten zijn schol, tong, tarbot, griet en stekelrog. De omstandigheden op zee werden door negen abiotische variabelen gedefinieerd: de tijd die de vis in het vangstverwerkingsproces zit, waterdiepte, type zeebodem, golfhoogte, watertemperatuur aan het oppervlak, luchttemperatuur, windsnelheid, de totale hoeveelheid vangst en de trekduur. De gegevens over de overlevingskansen en de abiotische variabelen werden in voorgaande studies verzameld door Van Marlen et al. (2016), Schram \& Molenaar (2018) en Molenaar \& Schram (2018).

De gebruikte data zijn afkomstig uit conventionele pulsvisserij waarin gebruik gemaakt wordt van een droge bak om de vangsten in te storten (behandeling $C$ ) en uit aangepaste pulsvisserij waarbij de stortbak gevuld werd met water (behandelingen $\mathrm{W}$ ). Schol en tong werden op twee punten in het vangstverwerkingsproces verzameld: op de sorteerband (s) en op de opvoerband tussen de stortbakken en de sorteerband (c). Dit resulteerde in vier behandelingen Cs, Cc, Ws en Wc voor schol en tong. Tarbot, griet en stekelrog werden alleen voor de conventionele pulsvisserij verzameld op de sorteerband (Cs). Voor deze soorten was dus geen sprake van verschillende behandelingen. De totale aantallen testvissen vanuit de verschillende gebruikte studies waarvoor de overleving is gemeten en die zijn meegenomen in de statistische analyses bedragen 1694 voor schol, 751 voor tong, 110 voor tarbot, 90 voor griet en 94 voor stekelrog. Omdat niet alle abiotische variabelen altijd zijn vastgelegd voor elke testvis, hangt het aantal beschikbare waarnemingen af van welke abiotische variabelen gebruikt werd in een analyse.

De statistische methode Generalized linear mixed models is gebruikt om discardsoverlevingsdata te analyseren. Aan elk model werd een fixed term toegevoegd om te corrigeren voor (mogelijke) verschillen in overleving tussen de behandelingen. Door toevoeging van een random effect voor reis aan het model werd rekening gehouden met mogelijke afhankelijkheden tussen de verschillende trekken waaruit vissen zijn verzameld. Om inzicht te krijgen in het belang van de verschillende abiotische variabelen werd als eerste het effect van elke individuele abiotische variabele afzonderlijk getest. Daarvoor werden alle beschikbare data voor de betreffende variabele gebruikt. Vervolgens werd stapsgewijs middels forward selection een verklarend model voor discards overlevingskans geconstrueerd. Tot slot werden interacties tussen behandelingen en abiotische variabelen onderzocht. Op basis van dit onderzoek komen wij tot de volgende conclusies:

- De overlevingskans van in zee teruggezette bijvangsten in de pulsvisserij hangt af van de omstandigheden op zee tijdens de visserij. Welke abiotische variabelen van belang zijn voor de overlevingskans, hangt af van de vissoort.

- De overlevingskans van schol discards hangt af van het type zeebodem waarop gevist wordt wanneer gebruik gemaakt wordt van een met water gevulde stortbak. De overlevingskans is het hoogst op zachte, modderige zeebodems en het laagst op stenige zeebodems. Wanneer de conventionele droge stortbak gebruikt wordt maakt het type zeebodem niet uit voor de overlevingskans van schol discards.

- De overlevingskans van schol discards hangt af van de totale hoeveelheid vangst in een trek wanneer gebruik gemaakt wordt van een met water gevulde stortbak. De overleving is hoger als de vangsten kleiner zijn. Als de hoeveelheid vangst toeneemt, neemt de overlevingskans voor de waterbak sneller af dan voor de droge stortbak, waardoor bij grote vangsten de overleving voor de waterbak uiteindelijk lager is dan voor de droge stortbak. 
- De overlevingskans van schol discards hangt ook af van de temperatuur van het oppervlakte water. Zowel voor de droge als met water gevulde stortbak neemt de overlevingskans af met stijgende temperatuur.

- De overlevingskans van tong discards hangt af van de hoeveelheid vangst in de trek en de golfhoogte. Zowel voor de droge als met water gevulde stortbak neemt de overlevingskans af met toenemende hoeveelheid vangst en toenemende golfhoogte.

- Voor griet werden geen effecten van abiotische variabelen op de overlevingskans van discards gevonden. Dit komt waarschijnlijk doordat het aantal waarnemingen klein is. Het is ook mogelijk dat griet zo gevoelig is dat de vis in veel gevallen dermate beschadigd wordt door het proces van vangen, halen en vangst verwerken dat de condities op zee weinig meer uitmaken.

- Voor stekelrog werd enig bewijs gevonden voor net zo'n effect van het type zeebodem waarop gevist wordt als werd gevonden voor schol.

- De overlevingskans van tarbot discards hangt af van de (lucht) temperatuur. De overlevingskans neemt toe met stijgende temperatuur.

- De overlevingskans van tarbot discards hangt ook af van de windsnelheid (golfhoogte) en de totale hoeveelheid vangst in een trek. De overlevingskans neemt af met toenemende windsnelheid en toenemende vangst hoeveelheid in de trek.

- Voor tarbot werd enig bewijs gevonden voor een effect van de tijd die de vis in het vangstverwerkingsproces zit op de overlevingskans van discards. De overlevingskans neemt af naarmate de vis langer in het verwerkingsproces zit. 


\section{Introduction}

Demersal pulse-trawl fisheries in the North Sea is a mixed fishery that mainly targets Dover sole (Solea solea) and plaice (Pleuronectes platessa). Bycatches like undersized or over quota fish and species with no market value are discarded. By 2019 this practise of discarding will be restricted for all quota regulated species by the implementation of a landing obligation under the Common Fisheries Policy (European Union, 2013). As a result of this legislation, fishermen will be forced to land all undersized, damaged and marketable fish of species under quota management, also referred to as a landing obligation (LO). This landing obligation allows exemptions for species which, according to the best available scientific advice, have a high survival probability when released into the sea, taking into account gear characteristics, fishing practices and the ecosystem.

In 2018 we reported a discards survival probability estimate of $14 \%$ (95\%CI $11-18 \%$ ) for plaice in the conventional $80 \mathrm{~mm}$ pulse-trawl fisheries as the overall result of nine sea trips conducted in 2017 and 2018 (Schram and Molenaar, 2018). This estimate agreed well with the previously reported survival probability of plaice discards in pulse-trawl fisheries of $15 \%$ (95\%CI 11-19\%) based on research conducted in 2015 (Van der Reijden et al., 2017).

In general the variation in the observed discards survival was high among the sea trips performed throughout the year. Among the nine individual sea trips in the 2018 project the discards survival of plaice ranged from 1 to $22 \%$ (Schram and Molenaar, 2018). This variation in survival probability might be due to varying environmental conditions and operational factors among fishing trips rather than experimental variation. Indeed, in the 2015 project it was already established that water temperature affects discards survival (Van der Reijden et al., 2017).

In both the 2015 and the 2018 project the discards survival probability for the conventional practise of discharging the catches into dry-hoppers was compared to discharging catches into water-filled hoppers. The effect of the water-filled hopper on survival was found to vary among sea trips and a generic positive effect of the water filled hopper was not detected (Molenaar and Schram, 2018). However, when considering individual sea trips, survival was found to be higher among plaice collected from the water filled hopper for three sea trips and lower (although not significant) for three other sea trips. These observations suggest that the effect of the water filled hopper on discards survival interacts with conditions during its use; using a water filled hopper may have a negative, positive or no effect on discards survival compared to a dry hopper depending on the conditions at sea.

Based on these findings, we hypothesized that discards survival is affected by the conditions at sea during the fishing activity with possibly different effects when employing a water filled hopper. In the current study we therefore 1 . assessed the effect of conditions at sea on the discards survival probability of plaice, sole, turbot, brill and thornback ray, and 2. assessed whether there are interactions between the hopper treatment and conditions at sea for plaice and sole. Data on discards survival probability and abiotic variables used in this study were previously collected in discards survival studies by Van Marlen et al. (2016), Schram and Molenaar (2018) and Molenaar and Schram (2018). 


\section{$2 \quad$ Materials and Methods}

\section{$2.1 \quad$ Data}

\subsubsection{Data collection - discards survival}

The effect of abiotic variables on the survival probability of fish discarded in pulse trawl fisheries was assessed. Pulse trawling involves double gears equipped with electrodes to electrically stimulate flatfish out of the sediment. The current assessment uses data collected in two separate projects. The first project (Van Marlen et al., 2016) was executed in 2015 and included eight sea trips with pulse trawlers. The second project (Schram and Molenaar, 2018) was executed in 2017 and 2018 and included nine sea trips with pulse trawlers. All pulse trawling in both projects involved $12 \mathrm{~m}$ gears and codends with a mesh size of $80 \mathrm{~mm}$.

The experimental procedures were essentially the same for both projects and are described in detail in Van Marlen et al. (2016) for the first project and in Molenaar and Schram (2018) for the second project. In brief: discards survival probabilities in the conventional pulse trawl fisheries were assessed under commercial fishing conditions. Sea trips were spread over the year to account for potential seasonal variation in discards survival and abiotic conditions. Test-fish were randomly collected from the end of the sorting belt at both the start and the end of the catch-sorting process from multiple hauls per sea trip. In some cases test fish were sampled from the conveyor belt between the hoppers and the sorting belt. Reflex impairment and damages were assessed for all test-fish and summarized in a vitality index score. Test-fish were housed on-board in custom-built monitoring units containing 16 (24L) tanks with five fish in each tank for sole and plaice. Turbot and brill were housed with 3 fish in a tank and thornback rays were kept individually. Tank water was continuously renewed with sea water at a rate of at least two tank volumes per hour to maintain proper water quality. Survival was monitored daily and dead fish were removed upon detection. Upon arrival in the vessel's home port, monitoring units were road transported to the laboratory to continue survival monitoring for two more weeks. The total monitoring period ranged from 15 to 18 days depending on the day of collection at sea. In the laboratory, tank bottoms were covered with coarse sand and fish were fed natural food. Control-fish of the same species, previously collected at sea and in good condition, were deployed during all sea trips in numbers approximating $20-25 \%$ of the total number of test-fish collected per sea trip. Control-fish were handled and tagged as test-fish to separate fisheries related mortality from mortality caused by the experimental procedures. The methodology was in accordance with the International Council for the Exploration of the Sea (ICES) guidelines for discards survival studies (ICES, 2016). The treatment of the fish was in accordance with the Dutch animal experimentation act, as approved by ethical committees (Experiment 2017 D0012.002). Discards survival probabilities were calculated from counts of surviving fish at the end of the monitoring period.

In addition to measuring discards survival in the conventional pulse trawl fisheries (treatment $\mathrm{C}$ ), the effect of a water filled hopper (treatment $W$ ) was assessed by pairwise comparison to the conventional practise of a dry hopper (C) for plaice and sole. To this end the two treatments were installed at either side of a trawler during part of the sea trips. For both treatments the majority of test fish was sampled from the end of the sorting belt ( $s$ ) but during three sea trips test fish were also sampled from the conveyor belt between the hopper and the sorting belt (c). This resulted in two levels within treatments C and W: Cs, Cc, Ws and Wc. Table 1 provides an overview of the number of test-fish per treatment for each sea trip.

\subsubsection{Data collection - abiotic variables}

Except for wave height, data on the operational and environmental conditions (abiotic variables) were recorded by the skippers and researchers on-board of the pulse trawlers for each haul from which 
test-fish were collected. Data were recorded at the level of hauls within sea trips except for the time in the catch sorting process which was recorded at the level of the individual fish. Wave height data were obtained from the Directorate-General for Public Works and Water Management (Rijkswaterstaat) database. Wave heights recorded by 14 automatic measuring buoys in the North Sea were linked to individual hauls, based on date and time and location. In all cases the wave height recorded by the buoy nearest to the haul location was used with a maximum distance of $213 \mathrm{~km}$. Table 2 provides an overview of the recorded abiotic values, the recording method and the observed ranges for plaice. Note that the observed ranges may vary slightly for other fish species as these were partly collected from different hauls for which conditions at sea may be different. All variables are continuous except seafloor which is categorical with three categories: muddy, sandy, stony.

Table 1 Overview of sea trips and the number of test fish collected per species per trip.

\begin{tabular}{|c|c|c|c|c|c|c|c|c|c|c|c|c|c|c|c|c|}
\hline \multirow[t]{2}{*}{ Project } & \multirow[t]{2}{*}{ Trip $^{1}$} & \multirow[t]{2}{*}{ Vessel } & \multirow[t]{2}{*}{ Year } & \multirow[t]{2}{*}{ Month } & \multirow[t]{2}{*}{ Week } & \multicolumn{4}{|c|}{ Plaice } & \multicolumn{4}{|c|}{ Sole } & \multirow{2}{*}{$\begin{array}{c}\text { Turbot } \\
\mathrm{Cs}^{2} \\
\end{array}$} & \multirow{2}{*}{\begin{tabular}{l|} 
Brill \\
$\mathrm{Cs}^{2}$ \\
\end{tabular}} & \multirow{2}{*}{$\begin{array}{c}\text { Thornback } \\
\text { ray } \\
\mathrm{Cs}^{2} \\
\end{array}$} \\
\hline & & & & & & $\mathrm{Cs}^{2}$ & $\mathrm{Cc}^{3}$ & $W^{4}$ & $W c^{5}$ & $\mathrm{Cs}^{2}$ & $\mathrm{Cc}^{3}$ & $W s^{4}$ & $W c^{5}$ & & & \\
\hline 1 & 1 & $\mathrm{~A}$ & 2014 & Nov & 47 & 41 & - & - & - & 40 & - & - & - & - & - & - \\
\hline 1 & 2 & $B$ & 2015 & March & 11 & 60 & - & - & - & - & - & - & - & - & - & - \\
\hline 1 & 3 & $\mathrm{~A}$ & 2015 & April & 15 & - & - & - & - & 78 & - & - & - & - & - & - \\
\hline 1 & 4 & $\mathrm{~A}$ & 2015 & May & 17 & 43 & - & - & - & 42 & - & - & - & - & - & - \\
\hline 1 & 6 & B & 2015 & June & 24 & 57 & - & - & - & 42 & - & - & - & - & - & - \\
\hline 1 & 7 & $\mathrm{~A}$ & 2015 & July & 28 & 40 & 41 & - & 30 & 31 & 33 & - & 31 & - & - & - \\
\hline 1 & 8 & B & 2015 & July & 31 & 58 & 43 & - & 36 & 51 & 39 & - & 32 & - & - & - \\
\hline 1 & 10 & $\mathrm{~B}$ & 2015 & Sept & 39 & 47 & 89 & - & 74 & - & - & - & - & - & - & - \\
\hline 2 & 1 & $C$ & 2017 & May & 18 & 60 & - & 60 & - & 31 & - & - & - & 9 & 9 & 10 \\
\hline 2 & 2 & $B$ & 2017 & May & 21 & 59 & - & 59 & - & 30 & - & - & - & 11 & 12 & 11 \\
\hline 2 & 3 & $\mathrm{D}$ & 2017 & June & 24 & 60 & - & 60 & - & 30 & - & - & - & 15 & 15 & 8 \\
\hline 2 & 4 & $\mathrm{D}$ & 2017 & July & 28 & 59 & - & 59 & - & 30 & - & - & - & 8 & 9 & 9 \\
\hline 2 & 5 & C & 2017 & Sept & 36 & 80 & - & - & - & 33 & - & - & - & 30 & 9 & 14 \\
\hline 2 & 6 & $D$ & 2017 & Oct & 44 & 60 & - & 60 & - & 30 & - & 28 & - & 12 & 9 & 14 \\
\hline 2 & 7 & B & 2017 & Dec & 49 & 60 & - & 60 & - & 30 & - & 30 & - & 9 & 8 & 9 \\
\hline 2 & 8 & C & 2018 & Jan & 4 & 60 & - & 60 & - & 30 & - & - & - & 9 & 10 & 10 \\
\hline 2 & 9 & B & 2018 & Feb & 8 & 59 & - & 60 & - & 30 & - & - & - & 7 & 9 & 9 \\
\hline
\end{tabular}

1) Trips 5, 9 and 11 of project 1 were omitted because these involved a twin-rig gear;

2) $\mathrm{Cs}=$ Conventional dry hopper, test fish sampled from the sorting belt;

3) $\mathrm{Cc}=$ Conventional dry hopper, test fish sampled from the conveyor belt;

4) Ws=Water filled hopper, test fish sampled from the sorting belt;

${ }^{5)} \mathrm{Wc}=$ Water filled hopper, test fish sampled from the conveyor belt.

Table 2 Abiotic variables recorded during the sea trips

\begin{tabular}{|c|c|c|c|c|}
\hline Abiotic variables & Level & Range of values & Unit & Method \\
\hline $\begin{array}{l}\text { Time in catch sorting } \\
\text { process }\end{array}$ & Fish & $1-34$ & $\min$ & $\begin{array}{c}\text { Time difference between catch on deck and } \\
\text { sampling as recorded by researchers }\end{array}$ \\
\hline Depth & Haul & $22-50$ & $\mathrm{~m}$ & Average during haul - navigation equipment \\
\hline Seafloor & Haul & Muddy, sandy, stony & - & $\begin{array}{l}\text { According to skipper's information and } \\
\text { navigation equipment }\end{array}$ \\
\hline Wave height & Haul & $0.3-2.6$ & $\mathrm{~m}$ & $\begin{array}{l}\text { Wave height measured by the nearest } \\
\text { Rijkswaterstaat buoy }\end{array}$ \\
\hline $\begin{array}{l}\text { Surface water } \\
\text { temperature }\end{array}$ & Haul & $4.0-20.0$ & ${ }^{\circ} \mathrm{C}$ & $\begin{array}{l}\text { As measured in the survival units by } \\
\text { researchers }\end{array}$ \\
\hline Air temperature & Haul & $6.0-20.0$ & ${ }^{\circ} \mathrm{C}$ & Thermometer outside the vessel's bridge \\
\hline Wind speed & Haul & $1-6$ & $\mathrm{Bft}$ & Navigation equipment \\
\hline Total catch mass* & Haul & $200-1600$ & $\mathrm{~kg}$ & Skipper's estimate \\
\hline Haul duration & Haul & $1.7-2.33$ & $\mathrm{hr}$ & Recorded by skipper \\
\hline
\end{tabular}


*) Total mass of unsorted catch of both trawls. Test-fish in the trawl were exposed to half of this mass.

\subsubsection{Data selection}

Data on discards survival and the operational and environmental conditions during test-fish collection were combined for both projects in one data set for the purpose of the current study. Included in the data were the treatments conventional fisheries (C) and water filled hopper (W) for plaice and sole sampled at the end of the sorting belt (s) and from the conveyor belt (c). This yielded a total of four treatments Cs, Cc Ws and Wc for plaice and sole which were all included in data. Test fish collected for each treatment were considered to be treated in a different way for which a correction was included in the statistical analyses (see below). All other treatments, i.e. shorter hauls (S) and a knotless cod-end $(\mathrm{N})$, and sampling points were excluded because there were too few observations. Turbot, brill and thornback ray were only collected for the conventional fishing practices and sampled at the end of the sorting belt (Cs) and thus have no treatment levels. Only sea trips with pulse-trawlers were included; the three sea trips with the twin-rig gear vessel were excluded. The resulting total number of observations at the level of test-fish is 1694 for plaice, 751 for sole, 110 for turbot, 90 for brill and 94 for thornback ray (Table 1 ). Not all abiotic variables were recorded for each observation. A complete data set, with no missing values for any of the abiotic variables in Table 2, contains 1020 observations for plaice and 526 observations for sole. As a result the number of observations available for statistical analysis depends on the selection of abiotic variables. Different lists of observations were employed per analysis (see also Results).

\subsection{Statistical procedures}

\subsubsection{Preliminary analyses}

Preliminary analyses revealed that survival probabilities were not the same for the sampling time (start and end of the catch-sorting process) within treatments Cs, Cc, Ws and Wc. These differences were however, with some exceptions, not significant, which is in line with earlier reports by Van Marlen et al. (2016) and Schram and Molenaar (2018) on the same data. The effect of abiotic variables on survival might be blurred by possible differences in survival probabilities between treatments. The effect of abiotic variables was therefore assessed in three ways: 1 . No correction for treatment; 2 . Correction for treatment and 3. Correction for treatment $*$ sampling time. There was generally little difference between the three correction methods (results not shown). It was decided to employ the simple correction for treatments, i.e. by including a fixed term for treatment in the model (see also below).

Pairwise correlations between the abiotic variables were calculated by including all units with values for each pair of variables. These correlations were based on (mean) values per \{sea trip, haul\} combinations.

\subsubsection{General procedure}

A generalized linear mixed model (GLMM) was used to analyse the observed survival data, separately for each species. A generalized linear model is appropriate because of the $0 / 1$ (dead or alive) response for which we assumed a binomial distribution with a logit link. Discards survival for different sea trips is assumed to be independent. This is appropriate because different sea trips have, by definition, different circumstances. Discards survival for different hauls within sea trips are not necessarily independent. To account for possible dependencies between hauls, a random sea trip effect was added to the model, implying equal correlations between hauls within a sea trip.

The GenStat procedure VSEARCH was used to perform stepwise forward selection of the abiotic variables starting from a model with a random sea trip effect and a fixed treatment term. In every 
step, the most significant abiotic variable (with $p$-value $\leq 0.05$ ) was added to the model as fixed effect until none of the remaining abiotic variables was significant. Predicted marginal probabilities for a model were obtained by integrating out the random sea trip effect employing Gauss-Hermite quadrature with 32 nodes.

\subsubsection{Stepwise model construction}

Because of the many missing abiotic values, model selection of abiotic variables was not straight forward. This is because inclusion or exclusion of abiotic variables led to different sets of observations to be used which in turn can lead to different selections of abiotic variables. To handle this situation, a stepwise approach was adopted employing different sets of variables. In case two abiotic variables are highly correlated, such as wind speed and wave height, inclusion of one of these in the model will prevent inclusion of the other variable. This implies that a careful examination of selected models and correlations is required.

As a first step the effect of single abiotic variables on survival probability was assessed, employing all the available data for that variable, to gain insights in the importance of individual abiotic variables. The number of observations varies for these single effect models. As a second step a stepwise forward selection of the abiotic variables was performed to construct an explanatory model for survival probability. This procedure employed only the test-fish for which the set of abiotic variables was complete. Based on the results, some of the abiotic variables were omitted or included, which resulted in new, larger or smaller complete data sets. Assessments were then re-addressed using the new data sets. The final model for a species was then constructed from the interpretation of the results of this stepwise approach. Omitted variables and their justifications are described in the results section.

Finally interactions between treatment and abiotic variables were investigated, mainly for those variables which were selected in the above stepwise approach. 


\section{Results}

\subsection{Correlations between abiotic variables}

Pairwise correlations between abiotic variables are presented in Table 3. Large positive correlations were observed for wave height and wind speed (0.84), wave height and haul duration (0.51), and surface water temperature and air temperature (0.80). Large negative correlations were observed for wave height and air temperature $(-0.58)$, surface water temperature and total catch mass $(-0.53)$, and air temperature and total catch mass $(-0.66)$.

Table 3 Pairwise correlations between abiotic variables.

\begin{tabular}{|l|c|c|c|c|c|c|c|c|}
\hline $\begin{array}{l}\text { Abiotic } \\
\text { variable }\end{array}$ & $\begin{array}{c}\text { Time in } \\
\text { catch } \\
\text { processing }\end{array}$ & Depth & $\begin{array}{c}\text { Wave } \\
\text { height }\end{array}$ & $\begin{array}{c}\text { Surface } \\
\text { water } \\
\text { temperature }\end{array}$ & Air \\
temperature & $\begin{array}{c}\text { Wind } \\
\text { speed }\end{array}$ & $\begin{array}{c}\text { Total catch } \\
\text { mass }\end{array}$ & Haul \\
duration \\
processing in catch
\end{tabular}

\subsection{Plaice}

\subsubsection{Effects of single abiotic variables}

The effect of individual abiotic variables on survival probability of plaice discards was assessed. To this end single variables were added to the model with treatment as fixed term employing all available observations for each individual abiotic variable. This yielded a significant effect of seafloor $(p=0.004)$ and surface water temperature $(p=0.013)$ (Table 4$)$. The effect of the single variable surface water temperature was found to be negative, indicating that survival decreases with increasing water temperature. Note that the estimate for Seafloor is missing because Seafloor is a factor with three levels (muddy, sandy, stony) and there is thus not a single estimate for this term.

Table 4 Effects of single abiotic variables on survival probability of plaice discards.

\begin{tabular}{|l|c|c|c|c|c|}
\hline Abiotic variable & \# Observations & Estimate & Standard error & F-value & P-value \\
\hline Time in catch processing & 1688 & -0.0186 & 0.0123 & 2.29 & 0.130 \\
\hline Depth & 1694 & 0.0064 & 0.0192 & 0.11 & 0.740 \\
\hline Seafloor & 1653 & $*$ & $*$ & 11.12 & 0.004 \\
\hline Wave height & 1576 & -0.1372 & 0.1920 & 0.51 & 0.475 \\
\hline $\begin{array}{l}\text { Surface water } \\
\text { temperature }\end{array}$ & 1694 & -0.1005 & 0.0348 & 8.35 & 0.013 \\
\hline Air temperature & 1402 & -0.0175 & 0.0526 & 0.11 & 0.742 \\
\hline Wind speed & 1653 & 0.0422 & 0.0734 & 0.33 & 0.565 \\
\hline Total catch mass & 1376 & 0.0624 & 0.3696 & 0.03 & 0.866 \\
\hline Haul duration & 1694 & -1.8667 & 1.0831 & 2.97 & 0.087 \\
\hline
\end{tabular}




\subsubsection{Forward selection of abiotic variables}

The variables air temperature, total catch mass and wave height were omitted because of their insignificance and many missing values (Table 4). The remaining abiotic variables were used for forward variable selection. This set of abiotic variables is complete for 1647 out of 1694 observations. In each step the most significant variable was added to the model (Table 5). Forward selection ultimately resulted in the selection of seafloor and surface water temperature as significant explanatory variables. All other abiotic variables were not required in an explanatory model for survival probability of plaice discards.

Table 5 Forward selection for a limited set of abiotic variables using 1647 observations.

\begin{tabular}{|c|c|c|c|c|c|}
\hline $\begin{array}{l}\text { Fixed term(s) } \\
\text { in the model } \\
\end{array}$ & Abiotic variable & Estimate & Standard error & F-value & P-value \\
\hline \multirow[t]{6}{*}{ Treatment } & Seafloor & $*$ & $*$ & 5.6 & 0.004 \\
\hline & $\begin{array}{c}\text { Surface water } \\
\text { temperature }\end{array}$ & -0.10 & 0.04 & 8.23 & 0.014 \\
\hline & Haul duration & -1.86 & 1.13 & 2.72 & 0.100 \\
\hline & $\begin{array}{c}\text { Time in catch } \\
\text { processing }\end{array}$ & -0.02 & 0.01 & 1.68 & 0.195 \\
\hline & Wind speed & 0.04 & 0.07 & 0.32 & 0.571 \\
\hline & Depth & 0.01 & 0.02 & 0.17 & 0.681 \\
\hline $\begin{array}{l}\text { Fixed term(s) } \\
\text { in the model } \\
\end{array}$ & Abiotic variable & Estimate & Standard error & F-value & P-value \\
\hline \multirow[t]{5}{*}{$\begin{array}{l}\text { Treatment \& } \\
\text { Seafloor }\end{array}$} & $\begin{array}{c}\text { Surface water } \\
\text { temperature }\end{array}$ & -0.08 & 0.04 & 5.17 & 0.041 \\
\hline & Wind speed & 0.10 & 0.07 & 1.93 & 0.165 \\
\hline & $\begin{array}{c}\text { Time in catch } \\
\text { processing }\end{array}$ & -0.02 & 0.01 & 1.92 & 0.166 \\
\hline & Haul duration & -1.08 & 1.12 & 0.92 & 0.338 \\
\hline & Depth & 0.00 & 0.02 & 0.01 & 0.907 \\
\hline $\begin{array}{l}\text { Fixed term(s) } \\
\text { in the model } \\
\end{array}$ & Abiotic variable & Estimate & Standard error & F-value & P-value \\
\hline \multirow{4}{*}{$\begin{array}{l}\text { Treatment, } \\
\text { Seafloor \& } \\
\text { Surface water } \\
\text { temperature }\end{array}$} & $\begin{array}{c}\text { Time in catch } \\
\text { processing }\end{array}$ & -0.02 & 0.01 & 1.95 & 0.16 \\
\hline & Wind speed & 0.08 & 0.07 & 1.25 & 0.26 \\
\hline & Haul duration & -1.07 & 1.05 & 1.03 & 0.31 \\
\hline & Depth & 0.00 & 0.02 & 0.03 & 0.86 \\
\hline
\end{tabular}

\subsubsection{Interaction effects}

A significant interaction between treatment and the most significant abiotic variable seafloor was detected $(p=0.003)$. This means that the effect of the seafloor on survival depends on the treatment. After adding this interaction to the model with surface water temperature, i.e. the model which was selected above, surface water temperature is on the brink of significance $(p=0.063)$. The predicted marginal survival probabilities of plaice sampled from the sorting belt for each combination of seafloor type and the dry (Cs) and water filled hopper (Ws) treatment are presented in Figure 1 for surface water temperatures of $6^{\circ} \mathrm{C}$ and $20^{\circ} \mathrm{C}$. The interaction between treatment and seafloor is mainly due to the much higher survival probability for the water filled hopper when used at muddy seafloors and the lower probability when used at stony seafloors. The predicted survival probabilities in relation to surface water temperature and their 95\% confidence intervals are presented in Figure 2 for the dry (Cs) and water filled hopper (Ws) treatments. For both treatments discards survival probability decreases with increasing surface water temperature. Note that the interaction between treatment and surface water temperature is not significant. 


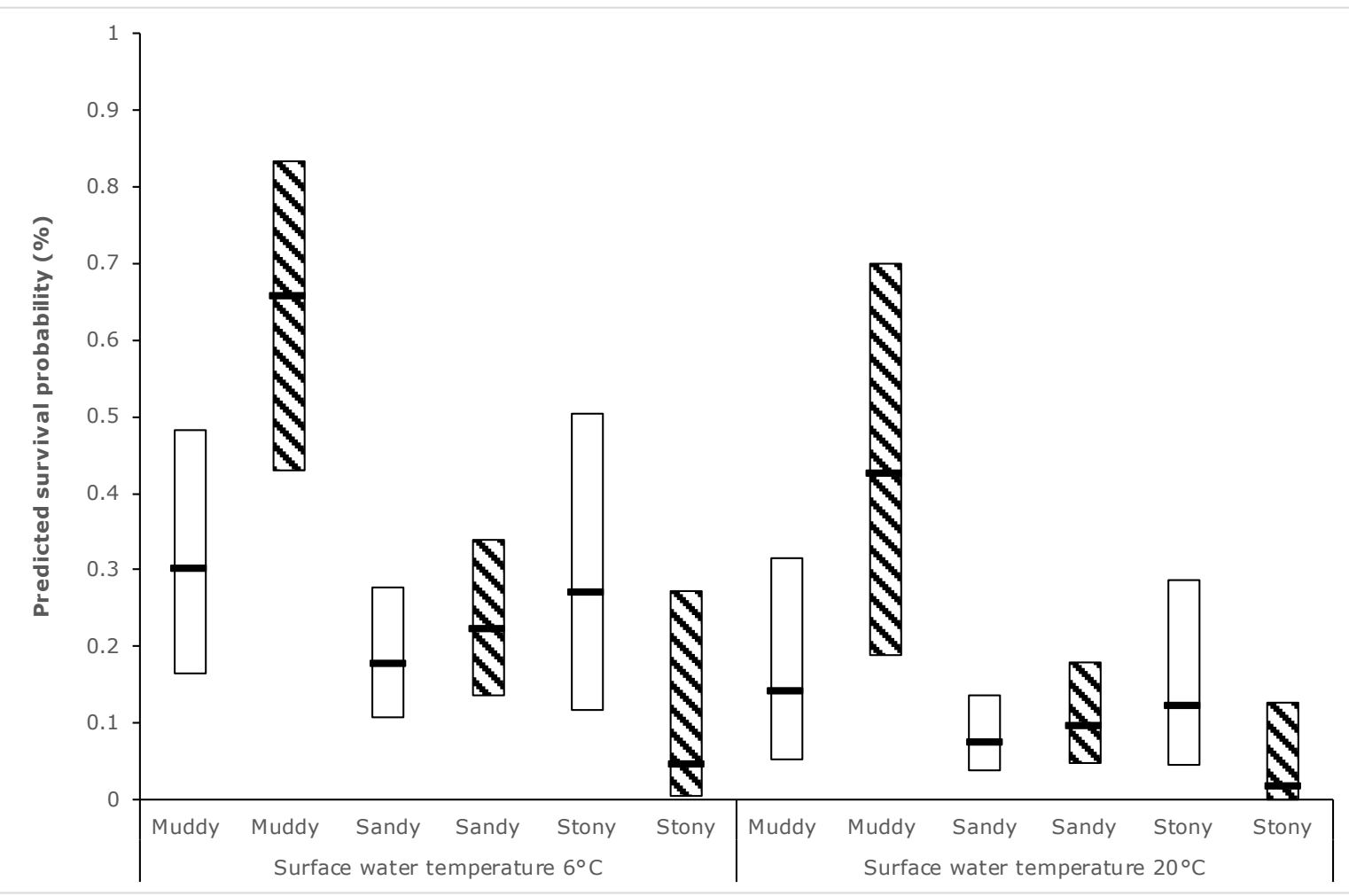

Figure 1 Interaction effects of seafloor and treatments dry (Cs - open boxes) or water filled hopper (Ws - shaded boxes) on predicted survival probability of plaice discards (horizontal lines) at surface water temperatures of $6^{\circ} \mathrm{C}$ and $20^{\circ} \mathrm{C}$. Predictions are based on the model treatment*seafloor + (surface water temperature). Boxes represent the $95 \%$ confidence intervals of predicted survival probabilities.

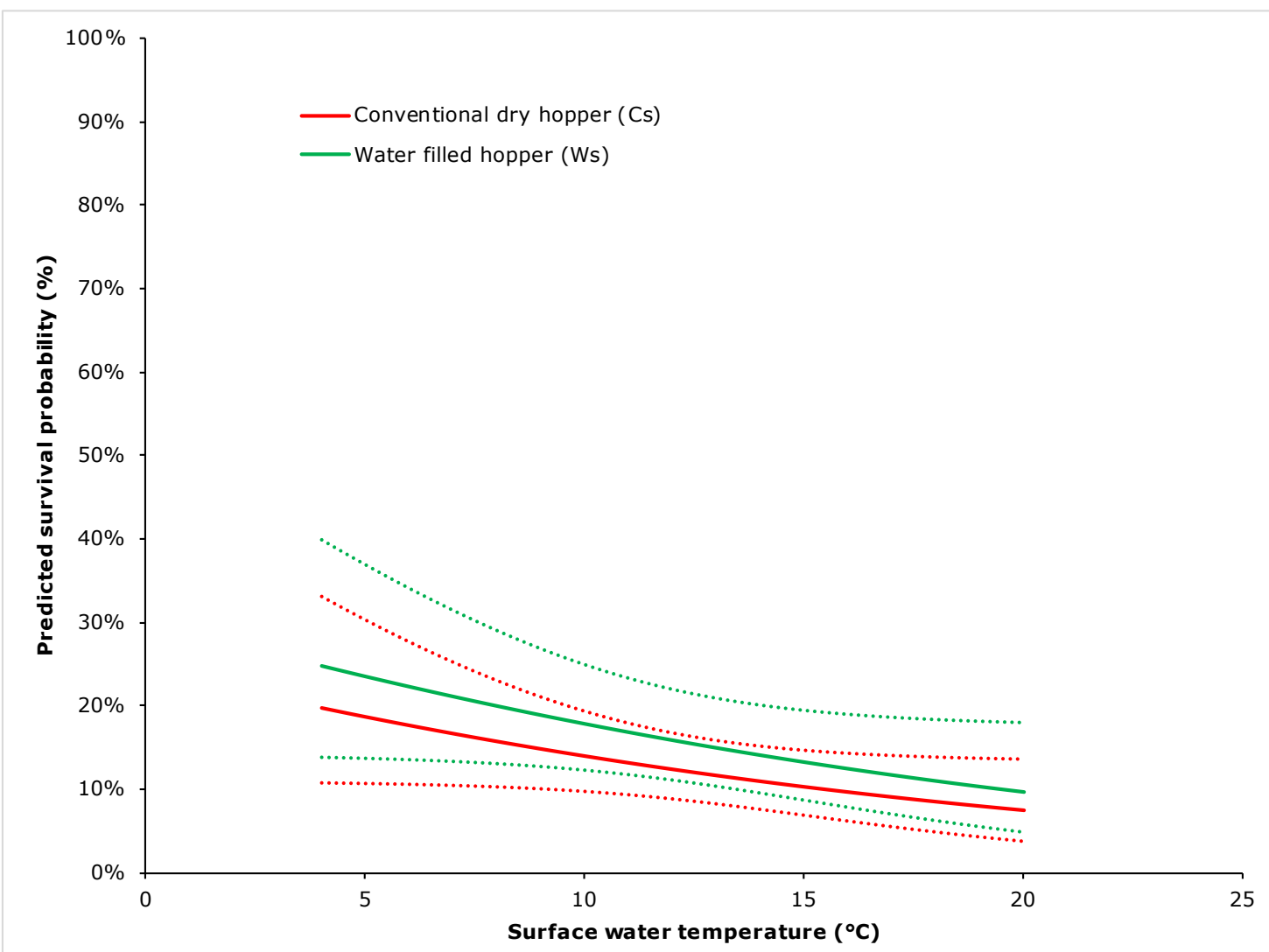

Figure 2 Effect of surface water temperature on the predicted survival probability of plaice discards when using a dry (Cs) or a water filled hopper (Ws) when trawling on a sandy seafloor. Dashed lines represent the $95 \%$ confidence intervals. Predictions are based on the model treatment*seafloor + (surface water temperature). 
Interactions of the other abiotic variables with treatment were tested for significance by adding these interactions to the model with the treatment*seafloor interaction; see Table 6 . This resulted in a significant interaction between treatment and total catch mass $(p=0.026)$ as well as treatment and haul duration $(p=0.039)$. Some evidence $(p=0.095)$ was found for an interaction between treatment and surface water temperature. Figure 3 displays the interaction between treatment and total catch mass for a sandy seafloor: the survival of the water filled hopper treatment declines faster with total catch mass than the conventional dry hopper treatment. The interactions treatment* haul duration and treatment*surface water temperature are due to different effects for test-fish sampled from the sorting belt (Cs and Ws) and the conveyor belt (Cc and Wc); i.e. effects of sampling point rather than hopper treatment. Consequently these interactions are not further explored.

Table 6 Interactions between treatment and abiotic variables when added to the model with a treatment*seafloor interaction

\begin{tabular}{|l|c|c|c|}
\hline Interaction & \# Observations & F-value & P-value \\
\hline Treatment* Time in catch processing & 1647 & 1.76 & 0.623 \\
\hline Treatment*Depth & 1653 & 5.67 & 0.129 \\
\hline Treatment*Wave height & 1535 & 1.83 & 0.609 \\
\hline Treatment*Surface water temperature & 1653 & 6.37 & 0.095 \\
\hline Treatment*Air temperature & 1402 & 5.15 & 0.161 \\
\hline Treatment*Total catch mass & 1335 & 9.27 & 0.026 \\
\hline Treatment*Haul duration & 1653 & 8.35 & 0.039 \\
\hline
\end{tabular}

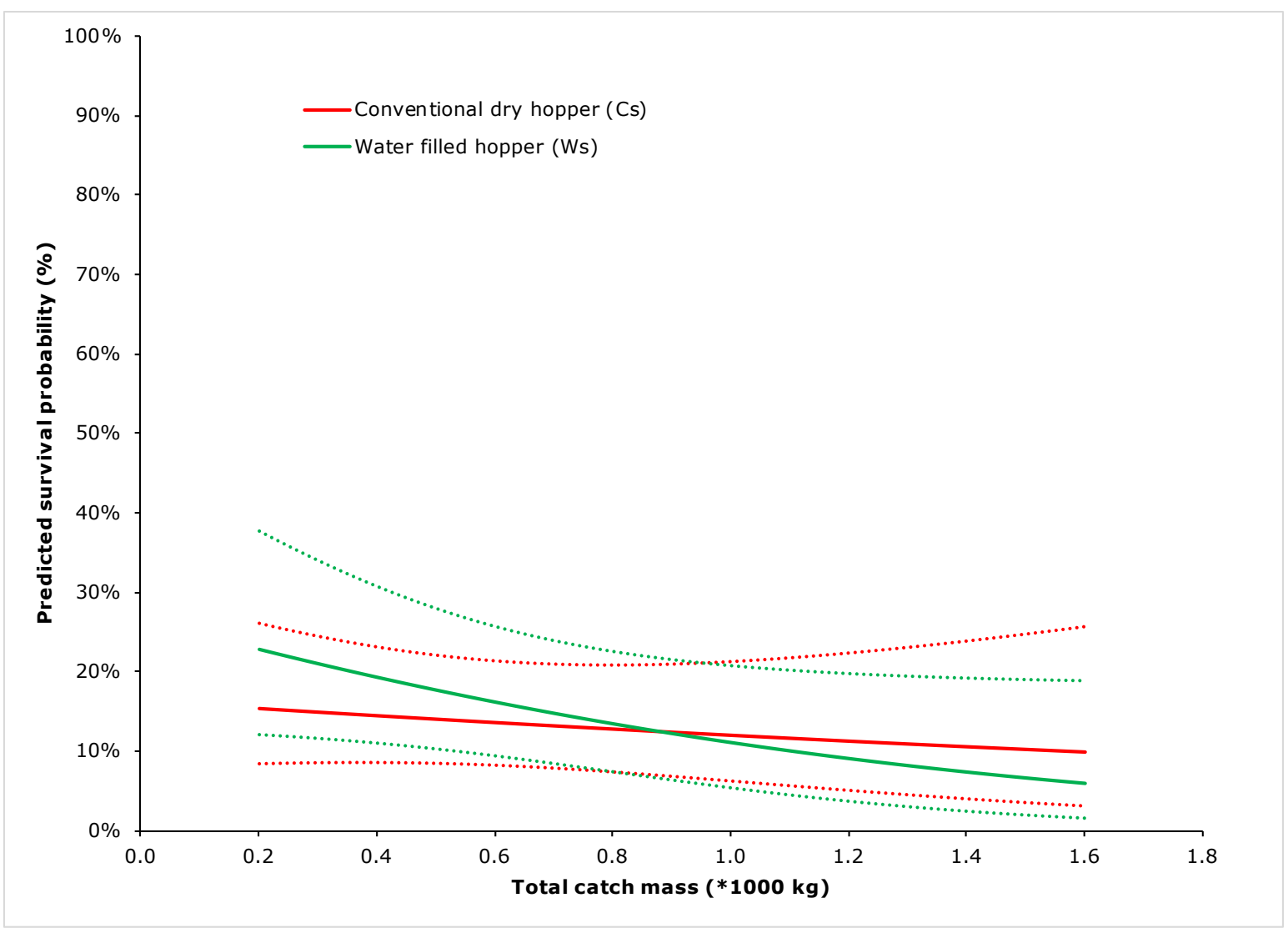

Figure 3 Effect of the amount of total catch mass in the trawl on the predicted survival probability of plaice discards when using a dry (Cs) or a water filled hopper (Ws) and trawling on a sandy seafloor. Dashed lines represent the 95\% confidence intervals. Predictions are based on the model treatment*seafloor + treatment*total catch mass. 


\subsection{Sole}

\subsubsection{Effects of single abiotic variables}

The effect of individual abiotic variables on survival probability of sole discards was assessed. To this end single variables were added to the model with a correction for treatment employing all available observations for each individual abiotic variable (Table 7). This yielded a significant negative effect of total catch mass $(p=0.023)$ and wave height $(p=0.043)$.

Table 7 Effects of single abiotic variables on survival probability of sole discards.

\begin{tabular}{|l|c|c|c|c|c|}
\hline $\begin{array}{l}\text { Abiotic } \\
\text { variable }\end{array}$ & \# Observations & Estimate & Standard error & F-value & P-value \\
\hline $\begin{array}{l}\text { Time in catch } \\
\text { processing }\end{array}$ & 748 & -0.0083 & 0.0190 & 0.19 & 0.664 \\
\hline Depth & 751 & -0.0326 & 0.0269 & 1.47 & 0.226 \\
\hline Seafloor & 711 & 0.2365 & 0.4485 & 0.28 & 0.598 \\
\hline Wave height & 721 & -0.5512 & 0.2722 & 4.10 & 0.043 \\
\hline $\begin{array}{l}\text { Surface water } \\
\text { temperature }\end{array}$ & 751 & 0.0541 & 0.0832 & 0.42 & 0.515 \\
\hline Air temperature & 616 & 0.0921 & 0.0582 & 2.51 & 0.113 \\
\hline Wind speed & 711 & -0.1288 & 0.1017 & 1.60 & 0.206 \\
\hline Total catch mass & 691 & -1.7121 & 0.7528 & 5.17 & 0.023 \\
\hline Haul duration & 751 & 2.0840 & 1.5783 & 1.74 & 0.187 \\
\hline
\end{tabular}

\subsubsection{Forward selection of abiotic variables}

Based on the single variable results, a model with treatment, total catch mass and wave height as fixed effects was fitted which employs 661 observations. Total catch mass $(p=0.015)$ and wave height $(p=0.010)$ were both significant, and there was a significant $(p=0.036)$ difference between treatments $(\mathrm{Cs}, \mathrm{Cc})$ on the one hand and (Ws, Wc) on the other hand. Interactions with treatment were not significant $(p=0.179$ and $p=0.924)$. Moreover, all remaining abiotic variables were not significant ( $p>0.099$ ) when added to the selected model. To illustrate the effect of total catch mass, the predicted marginal survival probabilities of sole are presented in Figure 4 for the dry (Cs) and water filled hopper (Ws) treatments at a wave height of $1 \mathrm{~m}$. To illustrate the effect of wave height, the predicted marginal survival probabilities of sole are presented in Figure 5 for the dry (Cs) and water filled hopper (Ws) treatments for a total catch mass of $1000 \mathrm{~kg}$. 


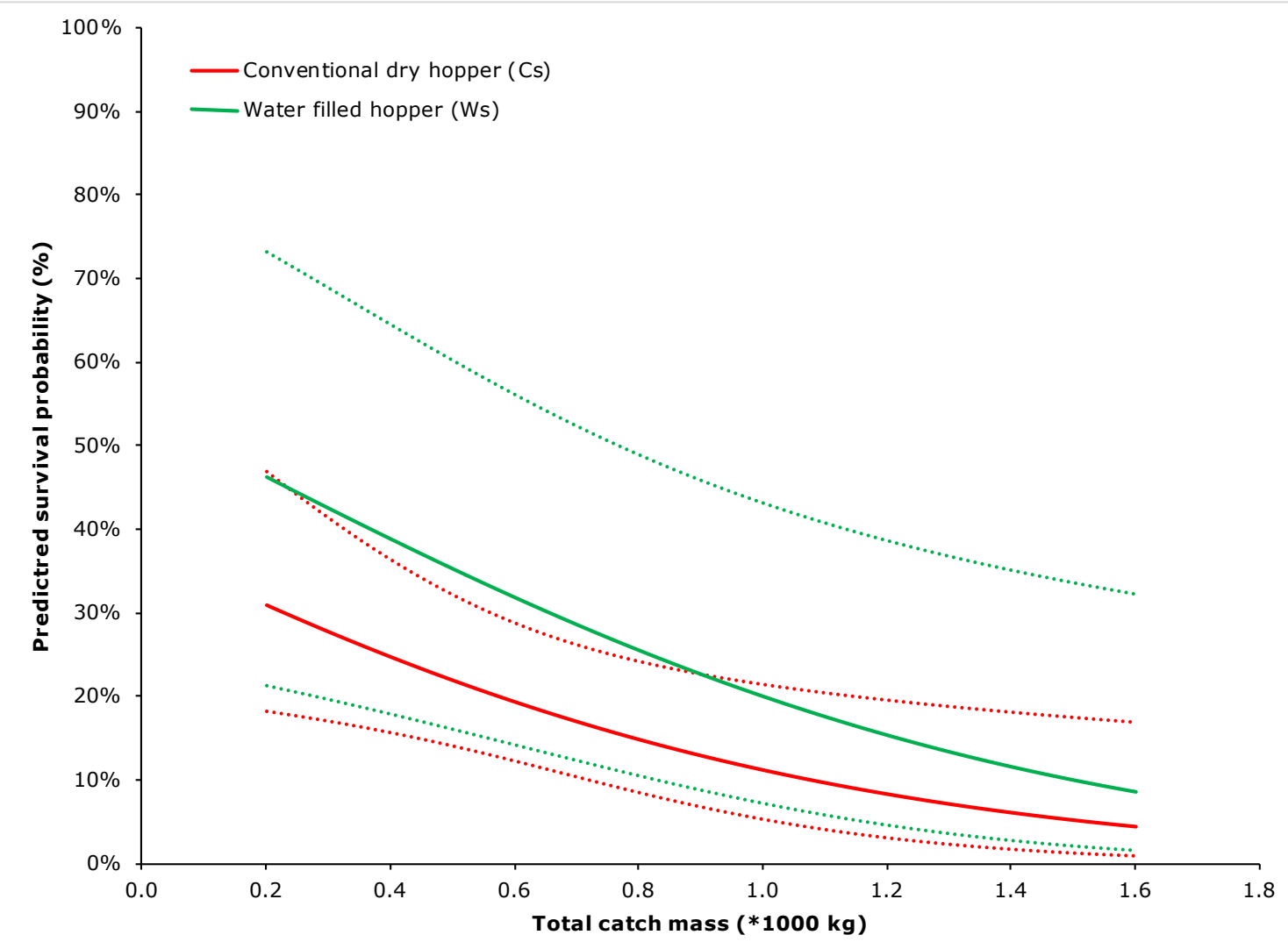

Figure 4 Effect of total catch mass on predicted survival probability of sole discards when using a dry (Cs) or a water filled hopper (Ws) at a wave height of $1 \mathrm{~m}$. Dashed lines represent the 95\% confidence intervals. Predictions are based on the model treatment + (total catch mass) + (wave height).

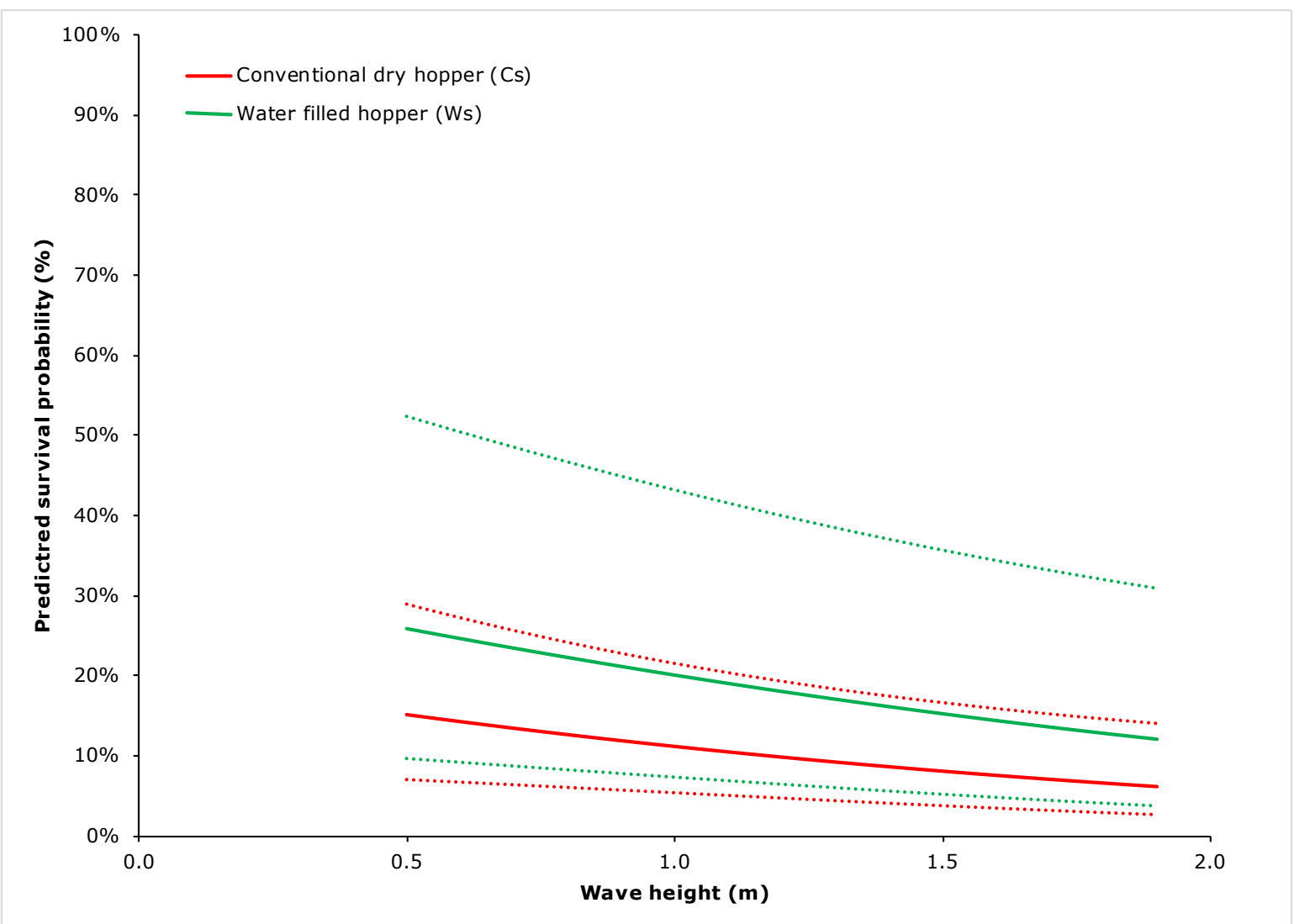

Figure 5 Effect of wave height on predicted survival probability of sole discards when using a dry (Cs) or a water filled hopper (Ws) and for a total catch mass of $1000 \mathrm{~kg}$. Dashed lines represent $95 \%$ confidence intervals. Predictions are based on the model treatment + (total catch) + (wave height). 


\subsection{Brill and thornback ray}

The effect of individual abiotic variables on survival probability of brill and thornback ray discards were assessed. Single variables were added to an empty model employing all available observations for each individual abiotic variable. Note that a fixed term for treatment was not needed because test fish for these species were collected from conventional pulse fisheries only. For brill none of the abiotic variables were significant (Table 8 ). For thornback back ray there was some evidence $(p=0.066)$ for an effect of seafloor (Table 9).

Table 8 Effects of single abiotic variables on survival probability of brill discards.

\begin{tabular}{|l|c|c|c|c|c|}
\hline $\begin{array}{l}\text { Abiotic } \\
\text { variable }\end{array}$ & \# Observations & Estimate & Standard error & F-value & P-value \\
\hline $\begin{array}{l}\text { Time in catch } \\
\text { processing }\end{array}$ & 89 & -0.0137 & 0.0736 & 0.03 & 0.853 \\
\hline Depth & 90 & 0.0176 & 0.0567 & 0.10 & 0.760 \\
\hline Seafloor & 90 & $*$ & $*$ & 0.00 & $*$ \\
\hline Wave height & 78 & 1.6598 & 1.0683 & 2.41 & 0.145 \\
\hline $\begin{array}{l}\text { Surface water } \\
\text { temperature }\end{array}$ & 90 & -0.0730 & 0.0940 & 0.60 & 0.458 \\
\hline Air temperature & 81 & -0.0280 & 0.0892 & 0.10 & 0.762 \\
\hline Wind speed & 90 & -0.0518 & 0.2339 & 0.05 & 0.828 \\
\hline Total catch mass & 66 & -1.2842 & 1.6744 & 0.59 & 0.458 \\
\hline Haul duration & 90 & -3.9556 & 5.5959 & 0.50 & 0.490 \\
\hline
\end{tabular}

Table 9 Effects of single abiotic variables on survival probability of thornback discards.

\begin{tabular}{|l|c|c|c|c|c|}
\hline $\begin{array}{l}\text { Abiotic } \\
\text { variable }\end{array}$ & \# Observations & Estimate & Standard error & F-value & P-value \\
\hline $\begin{array}{l}\text { Time in catch } \\
\text { processing }\end{array}$ & 86 & -0.0611 & 0.0527 & 1.34 & 0.246 \\
\hline Depth & 94 & -0.0125 & 0.0458 & 0.07 & 0.787 \\
\hline Seafloor & 94 & -2.6117 & 1.3986 & 3.49 & 0.066 \\
\hline Wave height & 83 & -0.5082 & 0.6143 & 0.68 & 0.408 \\
\hline $\begin{array}{l}\text { Surface water } \\
\text { temperature }\end{array}$ & 94 & 0.0960 & 0.0735 & 1.70 & 0.236 \\
\hline Air temperature & 84 & 0.1027 & 0.0712 & 2.08 & 0.192 \\
\hline Wind speed & 94 & -0.3193 & 0.1949 & 2.68 & 0.101 \\
\hline Total catch mass & 77 & -0.7029 & 0.8888 & 0.63 & 0.438 \\
\hline Haul duration & 94 & 1.5927 & 2.2046 & 0.52 & 0.470 \\
\hline
\end{tabular}

\subsection{Turbot}

\subsubsection{Effect of single abiotic variables}

Effects of individual abiotic variables on survival probability of turbot discards were assessed. Single variables were added to the model employing all available observations for each individual abiotic variable. Note that a fixed term for treatment was not needed in the model because test fish for turbot were collected from conventional pulse fisheries only. This yielded a significant positive effect of air temperature $(p=0.022)$ and a significant negative effect of wind speed $(p=0.002)$ (Table 10). In addition a negative effect of total catch mass was on the brink of significance $(p=0.052)$ while there was some evidence for a negative effect of time in catch processing $(p=0.065)$ (Table 10). The effects of wind speed and air temperature as single variables on predicted survival probability of turbot discards are given in Figure 6 and Figure 7. 
Table 10 Effects of single abiotic variables on survival probability of turbot discards.

\begin{tabular}{|l|c|c|c|c|c|}
\hline $\begin{array}{l}\text { Abiotic } \\
\text { variable }\end{array}$ & \# Observations & Estimate & Standard error & F-value & P-value \\
\hline $\begin{array}{l}\text { Time in catch } \\
\text { processing }\end{array}$ & 109 & -0.1049 & 0.0568 & 3.41 & 0.065 \\
\hline Depth & 110 & -0.0396 & 0.0454 & 0.76 & 0.389 \\
\hline Seafloor & 110 & $*$ & $*$ & 0.00 & 1.000 \\
\hline Wave height & 99 & 0.3931 & 0.6227 & 0.40 & 0.531 \\
\hline Surface water & & & & & \\
temperature & 110 & 0.1512 & 0.0892 & 2.87 & 0.121 \\
\hline Air temperature & 101 & 0.1993 & 0.0799 & 6.22 & 0.022 \\
\hline Wind speed & 110 & -0.5007 & 0.1570 & 10.17 & 0.002 \\
\hline Total catch mass & 87 & -8.6102 & 3.9265 & 4.81 & 0.052 \\
\hline Haul duration & 110 & -1.5621 & 4.0628 & 0.15 & 0.702 \\
\hline
\end{tabular}

\subsubsection{Forward selection of abiotic variables}

Although it seemed clear that survival of turbot discards depends on multiple variables, no final multivariable model was constructed because of the low number of observations.

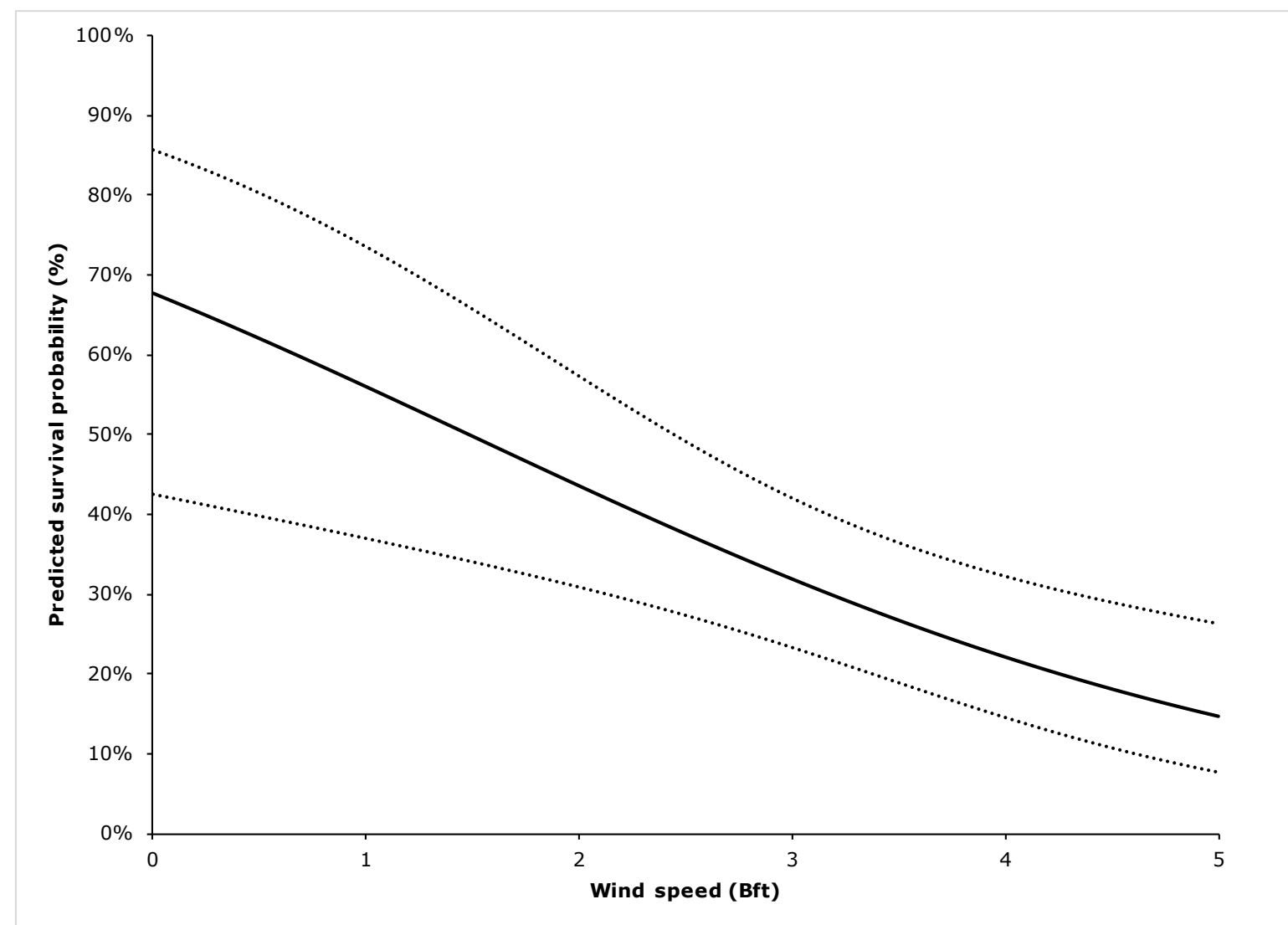

Figure 6 Effect of wind speed as single variable on the predicted survival probability of turbot discards in the $80 \mathrm{~mm}$ pulse trawl fisheries. The dotted lines represent the 95\% confidence interval. 


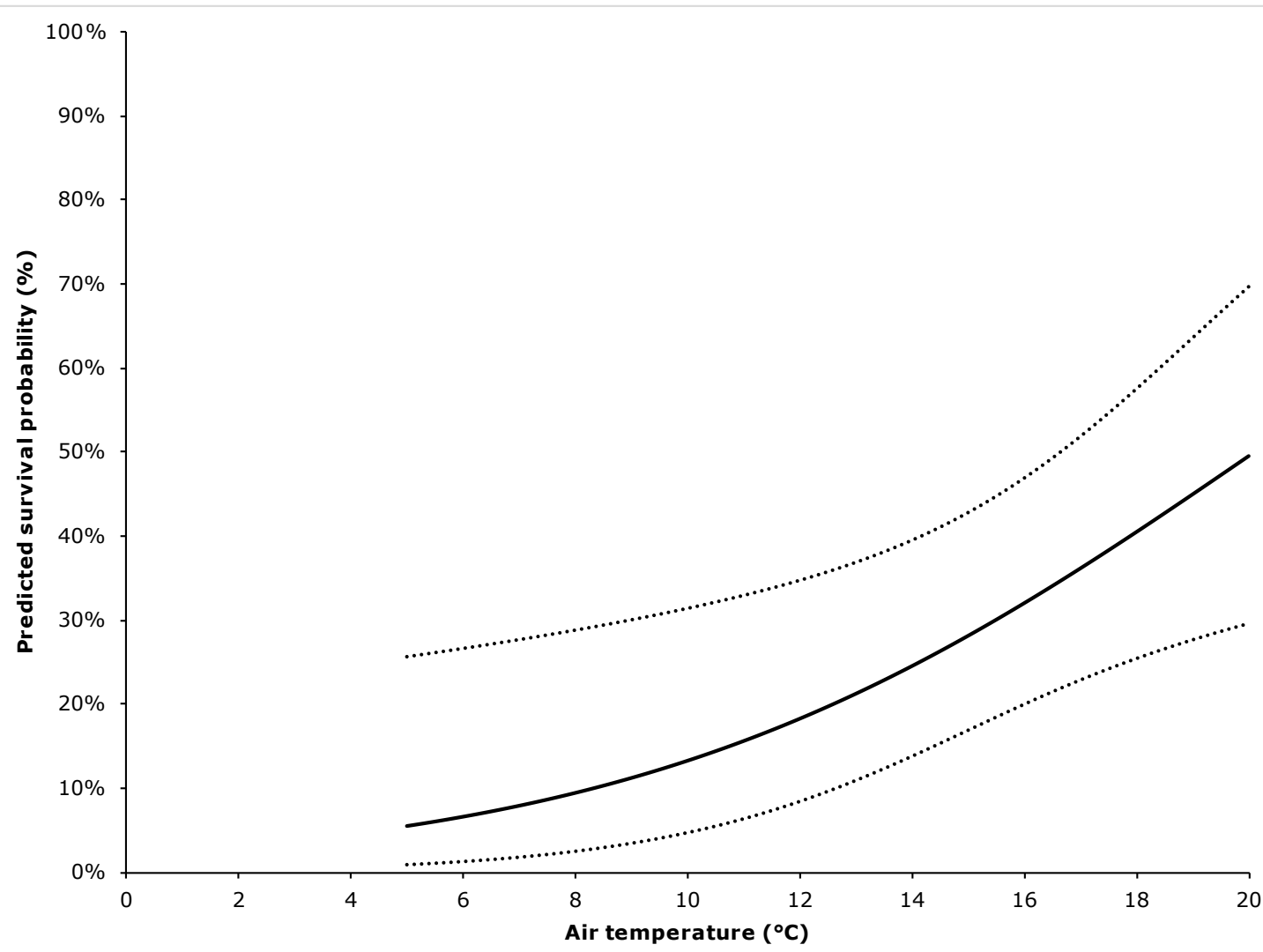

Figure 7 Effect of air temperature as single variable on the predicted survival probability of turbot discards in the $80 \mathrm{~mm}$ pulse trawl fisheries. The dotted lines represent the $95 \%$ confidence interval. 


\section{Discussion}

The relationship between the survival probability of five fish species discarded by the pulse trawl fisheries and conditions at sea were assessed. The fish species were plaice, sole, turbot, brill and thornback ray. The conditions at sea and operational factors were defined by the abiotic variables time in the catch sorting process, water depth, seafloor type, wave height, surface water temperature, air temperature, wind speed, total catch mass and haul duration. The data on discards survival probability and abiotic variables used in this study were previously collected by Van Marlen et al. (2016), Schram and Molenaar (2018) and Molenaar and Schram (2018). These studies showed large variation in discards survival observed under variable conditions at sea. The objective of this assessment was to increase our understanding of how the conditions at sea affect the survival probability of discarded bycatches. This is relevant for the development of measures aiming for increasing discards survival probabilities.

\subsection{Interaction between stressors and abiotic variables}

Fish discarded by commercial fisheries are exposed to multiple stressors during capture, handling and release (Cook et al., 2019). Stress in fish is well defined (Wendelaar Bonga, 1997) and involves a complex cascade of physiological processes aimed at immediate survival in threatening and challenging situations and ultimately re-establishing homeostasis (Wingfield et al., 1998 in Cook et al., 2019). The duration and the magnitude of the physiological disturbance following acute stress are proportional to the severity of the stressor. The severity of fisheries related stressors is influenced by environmental conditions as well as characteristics of the fishery (Cook et al., 2019). Since mortality ultimately results from failure to recover from the stress response and the impact of the stressor (Cook et al, 2019), abiotic variables that exacerbate the severity of stressor are clearly important for discards survival probability. Common stressors that may lead to mortality of fish caught by commercial fisheries include hypoxia, injury, exhaustion, barotrauma and predation. These stressors are described in detail by Cook et al. (2019). Their interactions with the abiotic variables addressed in the present study are discussed below. Predation on discarded bycatches is not considered as it could not occur in our studies.

Hypoxia or oxygen deficiency in tissues generally occurs during air exposure as a result of collapsed gill lamellae which drastically reduces the fish' gas exchange capacity. Hypoxia can also occur in the water in crowded nets due to local oxygen depletion and inability to move the operculum due to compression (Davis, 2002). Survival probability declines with increased duration of hypoxic conditions. Tolerance to the duration of hypoxia varies widely among fish species and can be affected by other stressors such as exhaustion. Characteristics of the fisheries such as haul duration, towing speed, total catch mass, temperature and catch processing time can affect the severity, incidence and duration of hypoxia. Longer hauls for example lead to larger catches which in turn lead denser crowding of fish in the codend and longer catch processing and thus longer air exposure. Higher towing speeds may lead to faster exhaustion, more dense crowding and increased compression of fish in the codend. Metabolic rates and oxygen demand increase with increasing temperature, while at the same time oxygen availability in the water is lower due to the decreasing water solubility of oxygen with increasing temperature. Both the impact of hypoxia and its incidence can therefore be expected to increase with increasing temperature.

Fisheries always involves some degree of internal or external injury of fish resulting from interactions between fish and fishing gear (Davis, 2002). Indeed, injuries were observed in nearly all fish sampled in our discards survival studies (Van Marlen et al., 2016; Schram and Molenaar, 2018) The type of injuries and their severity depend on the characteristics of the fisheries and the conditions at sea. Injuries such as loss of mucus layers, scale loss and skin damage result from fish contacting the gear, other fish, biota or debris in the catch and often result in delayed mortality (Cook et al., 2019). 
Crowding of fish in trawls typically results in bruising, crushing and constriction injuries as fish are pushed against the codend mesh, other biota and debris (Veldhuizen et al., 2018). Direct (delayed) mortality resulting from injuries depends on their nature, severity and ability of the fish to recover. Injuries can also lead to indirect mortality through secondary infections (Miller et al., 2014). Longer fishery activities, e.g. longer hauls, generally lead to more external injuries (Veldhuizen et al., 2018). An effect of haul duration probably acts through its positive effect on catch mass (Somerton et al., 2002) and time fish spend in the trawl. During data collection at sea, haul duration was standardized at 120 minutes. In practice however, this led to haul durations ranging from 102 to 140 minutes. Haul duration was included as variable in the current assessment but an effect on survival could not be detected, probably because of a lack of contrast within the available data. This agrees with our previous work in which no effect of reducing haul duration to 90 minutes on plaice discards survival was detected (Molenaar and Schram, 2018). Towing speed also has an effect on injuries but this could not be assessed in the current study because towing speed was equal among all observations. Sea state, here defined by abiotic variables wave height and wind speed, can be expected to exacerbate incidence and severity of injuries as for an increased physical strain on fish in the trawl during fishing, hauling, discharging cod-ends in hoppers and processing of fish on board as the seas become rougher. The effect of wind speed is probably indirect through the waves it causes.

Exhaustion is an integral part of trawl fisheries. Once in the trawl opening, fish (burst) swim along with the trawl until gradual exhaustion, depending on trawling speed and fish species swimming capacity and behavioural characteristics. With exhaustion fish gradually move towards the cod end of the trawl. In pulse trawling towing speeds ( 5 knots) are relatively high compared to otter trawling (2.5 knots) and although fish immediately regain their swimming capacity after electrical stimulation by the pulse field, the duration of swimming along with the trawl is probably short. Because of the high trawling speed in pulse trawling, fish will move relatively quickly towards the cod end. The extent to which the pulse trawling process exhausts fish remains to be established. Once in the cod end and possibly exhausted, fish are vulnerable to injuries from contacts with the net, other fish, biota and debris. Direct effects of exhaustion from excessive physical exercise include acute death as well as delayed mortality when the fish is unable to recover in time (Black 1957 \& Kieffer, 2000 in Cook et al., 2019). Towing speed and haul duration affect exhaustion, as well as temperature through an effect on swimming capacity (Davis, 2002).

Barotrauma is severe tissue damage as a result of internal build-up of gas. This occurs when fish rapidly ascent from generally more than $20 \mathrm{~m}$ depth to the water surface during hauling of the nets (Rudershausen et al., 2007). Although we did not observe bulging eyes, a typical sign of barotrauma (Humborstad et al., 2017), in our discards survival studies, we cannot entirely exclude it as a stressor in our studies. Less clear clinical signs include internal haemorrhaging, which we did not assess. In addition, the water depth in our studies exceeded $20 \mathrm{~m}$ in most cases. On the other hand, fish without swim bladders such as flatfish and rays are less vulnerable to barotrauma and in the current assessment we indeed did not detect any effect of depth on discard mortality in any of the investigated fish species.

The present study nor our previous studies (Van Marlen et al., 2016; Schram and Molenaar, 2018; Molenaar and Schram, 2018) attempted to establish causes of death of fish that died during discards survival monitoring. Although the causes of death of individual test fish are unknown, fish condition was established by scoring external damage and reflex impairment for all test fish. The resulting vitality index score was found to be related to survival probability (Schram and Molenaar, 2018). This provides certain insight in the possible causes of death and stressors involved at the level of individual fish. These insights can be used here to deduct plausible explanations for the relations between survival probability, abiotic variables and stressors inflicted on the fish during capture and catch processing.

In our discards survival studies, mortality mainly occurred as delayed mortality within the first days post capture. Acute mortality was low with more than $90 \%$ of the test fish alive at the moment of sampling. Although the causes of delayed mortality were not investigated, we consider physical internal and external injuries the most probable causes. We also do not rule out that exhaustion and sub lethal oxygen deficiencies sustained by the fish during catching and catch processing contributed 
to delayed mortality in part of the test fish. What can be ruled out as important causes of death are the experimental procedures and conditions in the discards survival studies as survival among the control fish in the experiments was high (Schram and Molenaar, 2018).

\subsection{Plaice}

For plaice we established an interaction between the type of seafloor at which the trawling takes place and the effect of the hopper treatment on discards survival probability. The hopper treatment consisted of comparing discards survival for the conventional practice of discharging catches from the codend into a dry hopper to discharging catches into a hopper filled with water. The hypothesis that the use of a water filled hopper results in higher discards survival was previously investigated by Molenaar and Schram (2018). The deployment of a water filled hopper did not result in a higher survival probability for plaice discards than a conventional dry hopper in year-round pulse-trawl fisheries. However, at the level of the individual sea trips, significant effects were found in three cases. Based on these observations we hypothesized that the effect of the water filled hopper on discards survival depends on the conditions at sea during its operation. This notion was further explored in the current study by assessing interaction effects between hopper treatments and abiotic variables. We now clearly established that when using the water filled hopper, discards survival of plaice depends on the type of seafloor the trawling takes place. Seafloors were classified as either muddy, sandy or stony. On muddy seafloors there is a distinct difference in survival, with the highest survival resulting from the use of the water filled hopper. On sandy seafloors, the vast majority of observations, the survival is lower and very similar for the dry and water filled hopper. The lowest survival is observed on the stony seafloor. Again there is a distinct difference between the two hopper treatments and this time the water filled hopper yields a lower survival than the conventional dry hopper. In contrast to the water filled hopper, discards survival resulting from the use of the conventional dry hopper is not affected by the type of seafloor.

In general the seafloor effect could be explained by a higher incidence of more severe injuries caused by collisions between fish and stones picked up by the trawl and retained in the codend on stony seafloors. On sandy seafloors, abrasion of the fish' skin by sand during trawling is likely to occur whereas the softer muddy seafloors may have less impact on the fish. It seems reasonable to assume that collisions with stones and abrasion by sand injures fish more or less irrespective of hopper treatment and fish species, although some species might differ in their sensitivity. In other words, it is reasonable to expect that the effect of seafloor type on discards survival is largely generic across fish species and hopper treatments. Surprisingly, a significant effect of seafloor could only be detected for plaice from the water filled hopper and to some extent for thornback ray $(p=0.06)$ from the conventional dry hopper. At present we have no explanation for the observation that survival of plaice discards is not negatively affected on a stony seafloor when using a dry hopper. It should be noted that the number of observations is very skewed for the seafloor types with relatively few observations for stony and muddy seafloors. In addition, the observations for stony seafloors are fully entangled with a single vessel. Therefore we cannot exclude that the negative effect of a stony seafloor when using a water filled hopper is in fact caused by variables associated to this vessel that we are unaware of. More balanced data for the three sea floor types on the survival of discards for both hopper treatments collected from multiple vessels is need to elucidate the current findings. The relation between hopper treatment, injuries and seafloor type could be further explored to explain our current observations. Such explorations, which are beyond the scope of the current study, would be limited to injury incidence as we did not classify injuries according to their severity.

The predicted survival for plaice discards discharged into a water filled hopper when trawling on a muddy seafloor is as high as $66 \%$ (at a water temperature of $6^{\circ} \mathrm{C}$ ). It is however doubtful that this is a realistic prediction because the maximum survival observed at sea is $45 \%$ (95\% CI $24-68 \%$ ) (Molenaar and Schram, 2018) and the water filled hopper being tested on muddy seafloors during three sea trips only with a total number of observations for plaice as low as 136.

Next to the model with a seafloor*treatment interaction, a significant interaction between treatment and total catch mass was detected. It seems that when catches are small, survival is higher when a 
water filled hopper is used. Survival for the water filled hopper declines faster with increasing catch mass than is the case for the dry hopper. This ultimately results in a lower survival for the water filled hopper compared to the dry at the largest catch masses. We previously postulated that negative effects of a water filled hopper on discards survival may act through depletion of dissolved oxygen (Molenaar and Schram, 2018). Fish are more prone to suffocation in water with low levels of dissolved oxygen than when exposed to air outside the water. This could be part of the explanation for the observed interactive effect of hopper treatment and total catch mass because oxygen depletion is more likely to occur as biomass in the hopper increases. Unfortunately we did not systematically measure dissolved oxygen levels during deployment of the water filled hopper and thus have no data that could corroborate this notion.

All other interactions between hopper treatment and abiotic variables were not significant. This is surprising as we hypothesized that when the sea is rough, e.g. high waves and high wind speeds, any positive effect of the water filled hopper on survival would be overruled by sloshing of water in the hopper. Sloshing, observed but not systematically recorded, could result in more injuries in fish through collisions with the hopper itself as well as other fish, benthic organisms and debris in the catch. Clearly this hypothesis is not supported by our data.

For plaice we also established a negative effect of surface water temperature on its survival probability irrespective of the hopper treatment. This means that survival probability of plaice discards decreases with increasing surface water temperature both for the use of a conventional dry hopper as a water filled hopper. Indeed, the highest survival of plaice discards were observed in winter while the lowest survival was observed during sea trips conducted in summer (Schram and Molenaar, 2018). A similar effect of temperature was previously detected for plaice discards by Van der Reijden et al. (2017) based on data collected by Van Marlen et al. (2016). We used the same data extended with data collected by Schram and Molenaar (2018) and this does not result in different findings regarding the effect of temperature on the survival of plaice discards. In contrast to plaice, we detected a significant positive effect of surface water temperature on the survival probability of turbot discards. It seems that even among flatfish species in the North Sea, the effect of temperature on discards survival can be different. Indeed the thermal biology of the two species is quite different with plaice (thermal range $2^{\circ}$ to $15^{\circ}$, Bristow, 1992) apparently being much more a cold water species than turbot (thermal range for growth $13^{\circ} \mathrm{C}$ to $22^{\circ} \mathrm{C}$, Imsland et al., 1997). Assuming that fish are more vulnerable at the extremes of their thermal ranges may explain why plaice displays lower survival at high surface water temperatures while turbot displays its lowest survival at low surface water temperature.

\subsection{Sole}

For sole discards we established negative effects of total catch mass and wave height on discards survival probability, both separately as single variables as well as combined in a multivariable model resulting from forward selection. These effects were independent of the hopper treatments as no significant interactions between treatment and abiotic variables were detected. Sole discards survival probability declines with increasing catch mass as well as wave height. A plausible explanation for both these negative effects is that with increasing catch mass and wave height the physical strain on fish in the trawl during fishing and hauling also increases. This could exacerbate the incidence and severity of injuries to the fish. In addition, the increased pressure on fish in the cod end could render fish more vulnerable to suffocation with the subsequent sub lethal hypoxia contributing to delayed mortality. To support this notion, the relations between injuries, wave height and catch mass could be explored. Such exploration, which is beyond the scope of the current study, would be limited to injury incidence as we did not classify injuries according to their severity. All other abiotic variables were not required in an explanatory model for survival probabilities of sole discards. This means that the incidence and severity of stressors that lead to mortality among sole discards are exacerbated nor alleviated by the other abiotic variables addressed in this study. From our visual observations at sea it is clear that a significant part of the sole in a catch ended up as meshed fish, although we did not quantify this proportion relative to the total sole catch. We previously established that meshed sole have a lower survival probability (Van Marlen et al., 2016). This effect of meshing possibly reduces the 
influence of abiotic variables on survival probability in case of sole discards. It surprising that no effect of temperature was detected because a negative effect of temperature on sole discards survival that was previously established by Van der Reyden et al. (2017) based on data collected by Van Marlen et al. (2016). We used the same data extended with data collected by Schram and Molenaar (2018) and this thus resulted in different findings regarding the effect of temperature on the survival of sole discards.

Similar to the effect of seafloor on plaice we would a priori expect the negative effects of catch mass and wave height on discards survival to be generic across fish species. However, no significant effects were detected in the other species in this study for these variables except turbot. The absence of significant effects of total catch mass and wave height in other species is possibly attributable to a low number of observations in case of brill and thornback ray and other variables masking the effect of catch volume and wave height in case of plaice.

\subsection{Brill and thornback ray}

For brill no significant effects on discards survival were detected for any of the abiotic variables tested. This could be due to the rather low number of observations for this species, although significant effects were detected for turbot based on very similar numbers of observations. Discards survival was lowest for brill among the five species tested (Schram and Molenaar, 2018) and so it seems that brill is very sensitive to fisheries related stressors and consequently lethally affected by the capture, hauling and catch sorting process irrespective of the conditions at sea.

In contrast to brill, thornback ray appears to be more robust to fisheries related stressors irrespective of the conditions at sea. Of all species tested, discards survival was the highest for thornback ray (Schram and Molenaar, 2018) and only for seafloor there is some evidence for an effect on survival probability. Indeed the numbers observations is low for thornback ray which may have hampered the detection of significant effects of abiotic factors. For both species more data on discards survival under various conditions are required to fully establish the influences of the conditions at sea on discards survival probability.

\section{$4.5 \quad$ Turbot}

For turbot we established a negative effect of wind speed and total catch mass. We attribute the effect of wind speed to its strong correlation to wave height. Although the assessment yielded a significant effect of wind speed and not of wave height, this is most likely not an effect of wind itself but of the waves caused by the wind. Similar to the explanation we proposed for sole, we'd explain the negative effects of wind speed and total catch mass through an increase in physical strain on fish in the trawl during fishing, hauling and catch processing with increasing wave height and catch mass. This could exacerbate the incidence and severity of injuries to the fish.

For turbot we also established a positive effect of air temperature on discards survival probability. This is consistent with our observations during the experimental work at sea in with higher survival in summer and lower survival winter (Schram and Molenaar, 2018). The effect of air temperature could also be an effect of water temperature; there is a strong correlation between the two temperatures. Note that we observed an opposite effect of surface water temperature on survival for plaice as discussed above. A water temperature effect could be explained by the ambient water temperatures in winter and summer in relation to the thermal range of turbot. In winter turbot discards survival is probably low because ambient water temperature reaches the lower limit of the thermal range of turbot, rendering it more vulnerable. Under these conditions, temperature probably exacerbates the severity of fisheries related stressors inflicted on the fish. In contrast, in summer ambient water temperatures are within the optimal thermal range of turbot (Imsland et al., 1997), rendering the fish less vulnerable compared to winter conditions. Alternatively, and not explored in the current study, the difference between water and air temperature may play a role as well.

Because of the low number of observations for turbot relative to plaice and sole, the construction of a multivariable explanatory model for the survival probability of turbot discards was not pursued. 
However, the single variable analyses seems to suggest that turbot discards survival is affected by multiple abiotic variables. This means that the effects of single variables as presented in Figure 6 and Figure 7 should be interpreted cautiously as they ignore the influence of other variables. These figures display the relation between survival and the respective variables but not necessarily the actual discards survival at sea. Clearly more data are required to fully establish the influences of the conditions at sea on survival probability of turbot discards.

\subsection{Conclusions}

- Survival of bycatches discarded in pulse trawl fisheries depends on the conditions at sea and operational characteristics of the fisheries. The abiotic variables that influence discards survival probability vary among species tested.

- The discards survival probability of plaice depends on the type of seafloor on which the trawling takes place in case a water filled hopper is used. On muddy seafloors there is a distinct difference in survival, with the highest survival resulting from the use of the water filled hopper. On sandy seafloors the survival is very similar for the dry and water filled hopper. On the stony seafloors the survival is lowest for the water filled hopper. When using the conventional dry hopper, discards survival of plaice is not affected by the type of seafloor.

- The discards survival probability of plaice depends on the total catch mass in case a water filled hopper is used. When catches are small, survival is higher when a water filled hopper is used. However, survival for the water filled hopper declines faster with increasing catch mass than is the case for the dry hopper, ultimately resulting in a lower survival for the water filled hopper.

- $\quad$ The discards survival probability of plaice also depends on the surface water temperature. Irrespective of hopper treatment, survival declines with increasing temperature.

- The discards survival probability of sole depends on total catch mass and wave height. Survival declines with increasing catch mass and wave height.

- For brill no effects of abiotic variables on discards survival probability could be detected, possibly because of a lack of observations. It is also possible that the species is very sensitive to fisheries related stressors and in many cases lethally affected by the capture, hauling and catch sorting process irrespective of the conditions at sea.

- For thornback ray some evidence was found for an effect of seafloor on discards survival probability similar to plaice.

- The discards survival probability of turbot depends on (air) temperature. Survival increases with increasing temperature.

- The discards survival probability of turbot also depends on wind speed (wave height) and total catch mass. Survival declines with increasing wind speed (wave height) and total catch mass.

- $\quad$ For turbot some evidence was found for an effect of time in the catch sorting process. Survival decreases with increasing time in the catch sorting process. 


\section{Quality Assurance}

Wageningen Marine Research utilises an ISO 9001:2015 certified quality management system. This certificate is valid until 15 December 2021. The organisation has been certified since 27 February 2001. The certification was issued by DNV GL.

Furthermore, the chemical laboratory at IJmuiden has NEN-EN-ISO/IEC 17025:2005 accreditation for test laboratories with number L097. This accreditation is valid until $1^{\text {th }}$ of April 2021 and was first issued on 27 March 1997. Accreditation was granted by the Council for Accreditation. The chemical laboratory at IJmuiden has thus demonstrated its ability to provide valid results according a technically competent manner and to work according to the ISO 17025 standard. The scope (L097) of de accredited analytical methods can be found at the website of the Council for Accreditation (www.rva.nl).

On the basis of this accreditation, the quality characteristic $Q$ is awarded to the results of those components which are incorporated in the scope, provided they comply with all quality requirements. The quality characteristic $Q$ is stated in the tables with the results. If, the quality characteristic $Q$ is not mentioned, the reason why is explained.

The quality of the test methods is ensured in various ways. The accuracy of the analysis is regularly assessed by participation in inter-laboratory performance studies including those organized by QUASIMEME. If no inter-laboratory study is available, a second-level control is performed. In addition, a first-level control is performed for each series of measurements.

In addition to the line controls the following general quality controls are carried out:

- Blank research.

- Recovery.

- Internal standard

- Injection standard.

- Sensitivity.

The above controls are described in Wageningen Marine Research working instruction ISW 2.10.2.105. If desired, information regarding the performance characteristics of the analytical methods is available at the chemical laboratory at IJmuiden.

If the quality cannot be guaranteed, appropriate measures are taken. 


\section{References}

Bristow, P., 1992. The illustrated encyclopedia of fishes. Chancellor Press, London. 303 p.

Cook, K.V., Reid, A.J., Patterson, D.A., Robinson, K.A., Chapman, J.M., Hinch, S.G., Cooke, S.J. 2019. A synthesis to understand responses to capture stressors among fish discarded from commercial fisheries and options for mitigating their severity. Fish and Fisheries 20, p 25-43.

Davis, M.W. 2002. Key principles for understanding fish bycatch discard mortality. Can. J. Fish. Aquat Sci. 59, p1834-1843.

European Union. 2013. REGULATION (EU) No 1380/2013 OF THE EUROPEAN PARLIAMENT AND OF THE COUNCIL of 11 December 2013 on the Common Fisheries Policy, amending Council Regulations (EC) No 1954/2003 and (EC) No 1224/2009 and repealing Council Regulations (EC) No 2371/2002 and (EC) No 639/2004 and Council Decision 2004/585/EC. Official Journal of the European Union, L354/22

ICES. 2016. Report of the Workshop on Methods for Estimating Discard Survival 4 (WKMEDS4), 30 November-4 December 2015, Ghent, Belgium. ICES CM 2015/ACOM: 39. 57 pp.

Humborstad, O. , Ferter, K. , Kryvi, H. and Fjelldal, P. G. 2017. Exophthalmia in wild-caught cod (Gadus morhua L.): development of a secondary barotrauma effect in captivity. J Fish Dis. 40, p41-49.

Imsland, A.K., Folkvord, A., Grung, G.L. Stefanson, S.O., Taranger, G.L. 1997. Sexual dimorphism in growth and maturation of turbot Scophthalmus maximus Rafinesque. Aquaculture Research 28 p. 101.114.

Molenaar, P. Schram, E. 2018. Increasing the survival of discards in North Sea pulse-trawl fisheries. Wageningen Marine Research Report C038/18.

Rudershausen, P.J., Buckel, J.A. Williams, E.H. 2007. Discard composition and release fate in the snapper and grouper commercial hook-and-line fishery in North Carolina, USA. Fisheries Management and ecology 14 (2), p 103-113.

Schram, E., Molenaar, P. 2018. Discards survival probabilities of flatfish and rays in North Sea pulsetrawl fisheries. Wageningen Marine Research Report C037/17.

Van der Reijden, K. J., Molenaar, P., Chen, C., Uhlmann, S.S., Goudswaard, P.C. Van Marlen, B. 2017. Survival of undersized plaice (Pleuronectes platessa), sole (Solea solea), and dab (Limanda limanda) in North Sea pulse-trawl fisheries. ICES Journal of Marine Science 74(6), 1672-1680.

Van Marlen, B., Molenaar, P., Van der Reijden, K.J., Goudswaard, P.C., Bol, R.A., Glorius, S.T., Theunynck, R., Uhlmann, S.S. 2016. Overleving van discard platvis - Vaststellen en verhogen. IMARES rapport C180/15, IMARES Wageningen UR.

Veldhuizen, L.J.L., Berentsen, P.B.M., De Boer, I.J.M., Van de Vis, J.W., Bokkers, E.A.M. 2018. Fish welfare in capture fisheries: A review of injuries and mortality. Fisheries Research 204, p. 41-48.

Wendelaar Bonga, S.E., 1997. The stress response in fish. Physiological Reviews 77, 591-625. 


\section{Justification}

Report C040/19

Project Number: 4311400003

The scientific quality of this report has been peer reviewed by a colleague scientist and a member of the Management Team of Wageningen Marine Research

Approved: $\quad$ Dr. ir. mw. N.A. Steins

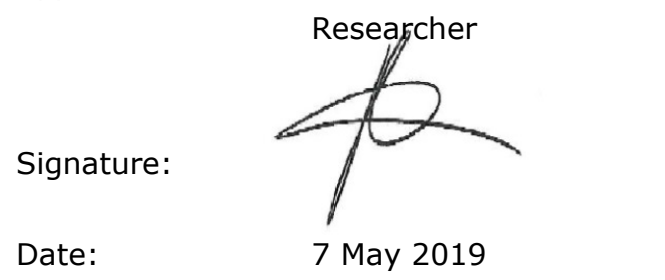

Approved: $\quad$ Dr. ir. T.P. Bult

Director

Signature:

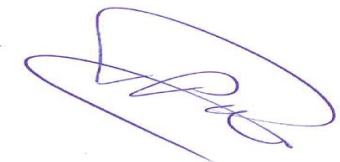

Date:

/ May 2019 
Wageningen Marine Research

T +31(0)317480900

E: marine-research@wur.nl

www.wur.eu/marine-research

Visitors' address

- Ankerpark 271781 AG Den Helder

- Korringaweg 7, 4401 NT Yerseke

- Haringkade 1, 1976 CP IJmuiden
With knowledge, independent scientific research and advice, Wageningen Marine Research substantially contributes to more sustainable and more careful management, use and protection of natural riches in marine, coastal and freshwater areas.
Wageningen Marine Research is part of Wageningen University \& Research. Wageningen University \& Research is the collaboration between Wageningen University and the Wageningen Research Foundation and its mission is: 'To explore the potential for improving the quality of life' 